\title{
External Liabilities and Crises
}

\author{
Luis A. V. Catão and Gian Maria Milesi-Ferretti
}




\title{
IMF Working Paper
}

\author{
Research Department
}

External Liabilities and Crises

Prepared by Luis A. V. Catão and Gian Maria Milesi-Ferretti ${ }^{1}$

May 2013

\section{This Working Paper should not be reported as representing the views of the IMF.} The views expressed in this Working Paper are those of the author(s) and do not necessarily represent those of the IMF or IMF policy. Working Papers describe research in progress by the author(s) and are published to elicit comments and to further debate.

\begin{abstract}
We examine the determinants of external crises, focusing on the role of foreign liabilities and their composition. Using a variety of statistical tools and comprehensive data spanning 1970-2011, we find that the ratio of net foreign liabilities (NFL) to GDP is a significant crisis predictor, and the more so when it exceeds 50 percent in absolute terms and 20 percent of the country-specific historical mean. This is primarily due to net external debt--the effect of net equity liabilities is weaker and net FDI liabilities seem if anything an offset factor. We also find that: i) breaking down net external debt into its gross asset and liability counterparts does not add significant explanatory power to crisis prediction; ii) the current account is a powerful predictor, either measured unconditionally or as deviations from conventionally estimated "norms"; iii) foreign exchange reserves reduce the likelihood of crisis more than other foreign asset holdings; iv) a parsimonious probit containing those and a handful of other variables has good predictive performance in- and out-of-sample. The latter result stems largely from our focus on external crises stricto sensu.
\end{abstract}

JEL Classification Numbers: E44, F32, F34, G15, H63

Keywords: International Investment Positions, Sovereign Debt, Currency Crises, Current Account Imbalances, Foreign Exchange Reserves.

Authors’ E-Mail Addresses: 1catao@imf.org; gmilesiferretti@imf.org

\footnotetext{
${ }^{1}$ We thank our discussant Cédric Tille, as well as Olivier Blanchard, Thierry Tressel, and participants of seminars at the Swiss National Bank, the IMF, and the Latin America and Caribbean Economic Association (LACEA) for comments on an earlier draft. We also thank Alan Taylor for suggesting us the use of the ROC approach, Jay Shambaugh for helpful discussions, and Marola Castillo for excellent research assistance. The usual caveats apply.
} 


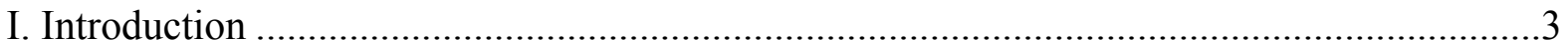

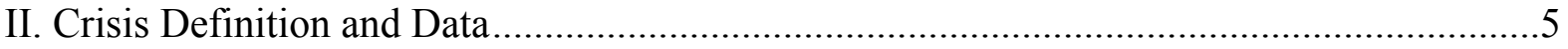

III. Crisis Dynamics and Model-Free Threshold Estimates...............................................

IV. Crisis Model....................................................................................................... 13

A. Model Selection Criterion ............................................................................. 13

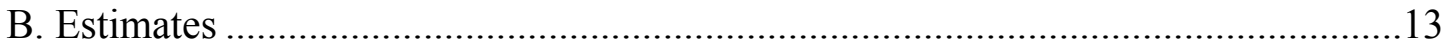

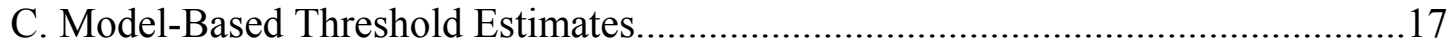

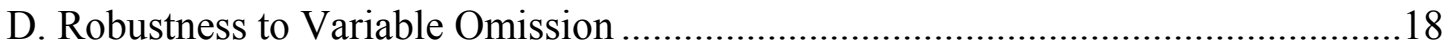

E. Robustness to Crisis Definition and Sample Breakdown....................................22

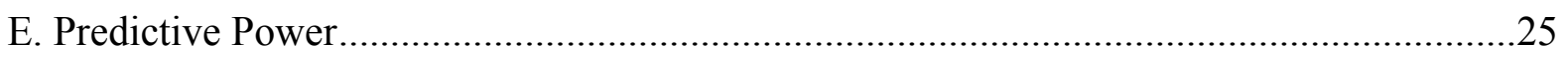

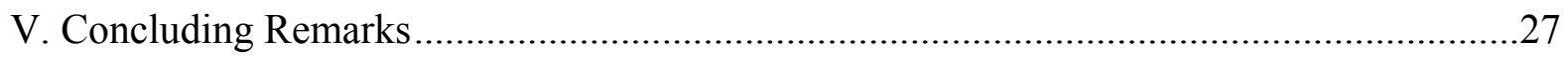

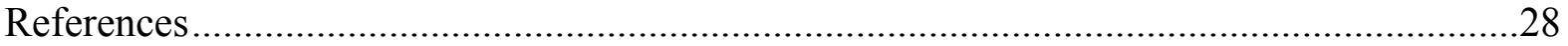

Figures

1. Net Foreign Liabilities of Selected Countries prior to the 2008-09 Crisis .......................3

2. Sample Distribution of External Crises ..................................................................

3. Unconditional Means of Selected Variables Around External Crises ...............................9

4. Conditional Mean of Selected Variables Around Crises ...............................................12

5. ROC curve for NFA only model.............................................................................. 14

6. Univariate Model: Threshold for NFA/GDP that Maximizes Signal to Noise.................18

Tables

1. AUROC Estimates for Various Model Specifications................................................15

2. Baseline Crisis Definition: Probit Estimates................................................................ 16

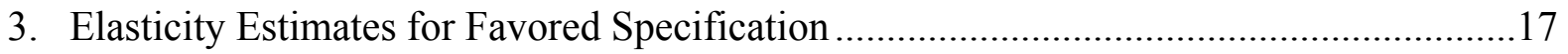

4. Multivariate Model's Tipping Point Estimates ............................................................... 18

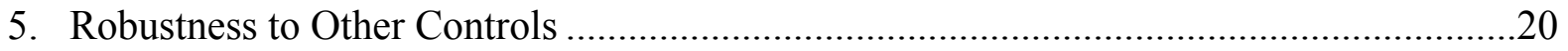

6. Robustness to Sample Definition and Estimation Period ............................................24

7. AUROC for Baseline Probit Using Different Crisis Definitions and

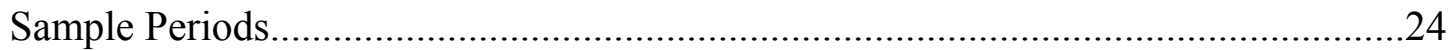

8. Baseline Probit Model: In-Sample Preditive Performance ...........................................25

9. Share of Good Signals to Total Crises by Regions......................................................26

10. Out-of-Sample Predictive Power over 2008-2011 Crises............................................26

Appendices

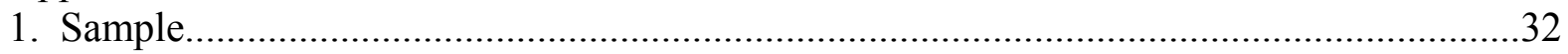

2. Estimates of Current Account Gaps...................................................................... 34 


\section{INTRODUCTION}

Large current account imbalances over the past decade have given rise to sizeable crosscountry differences in net foreign asset (NFA) positions, as documented by the extensive literature on global imbalances. While the global financial crisis was not associated with a "disorderly unwinding" of these imbalances, the potential role of high external liabilities in triggering crises has re-emerged in the wake of recent developments in the euro area: four countries at the epicenter of financial turmoil (Greece, Ireland, Portugal, and Spain) had NFA/GDP ratios between -70 percent (Ireland) and -90 percent (Portugal) at the onset of the crisis at end-2008. And a broader look at advanced economies and emerging markets with net foreign liabilities above 70 percent of GDP at the end of 2007 shows the high incidence of countries that have subsequently faced an external crisis (Figure 1, bars marked in red).

Figure 1. Net Foreign Liabilities of Selected Countries prior to the 2008-09 Crisis

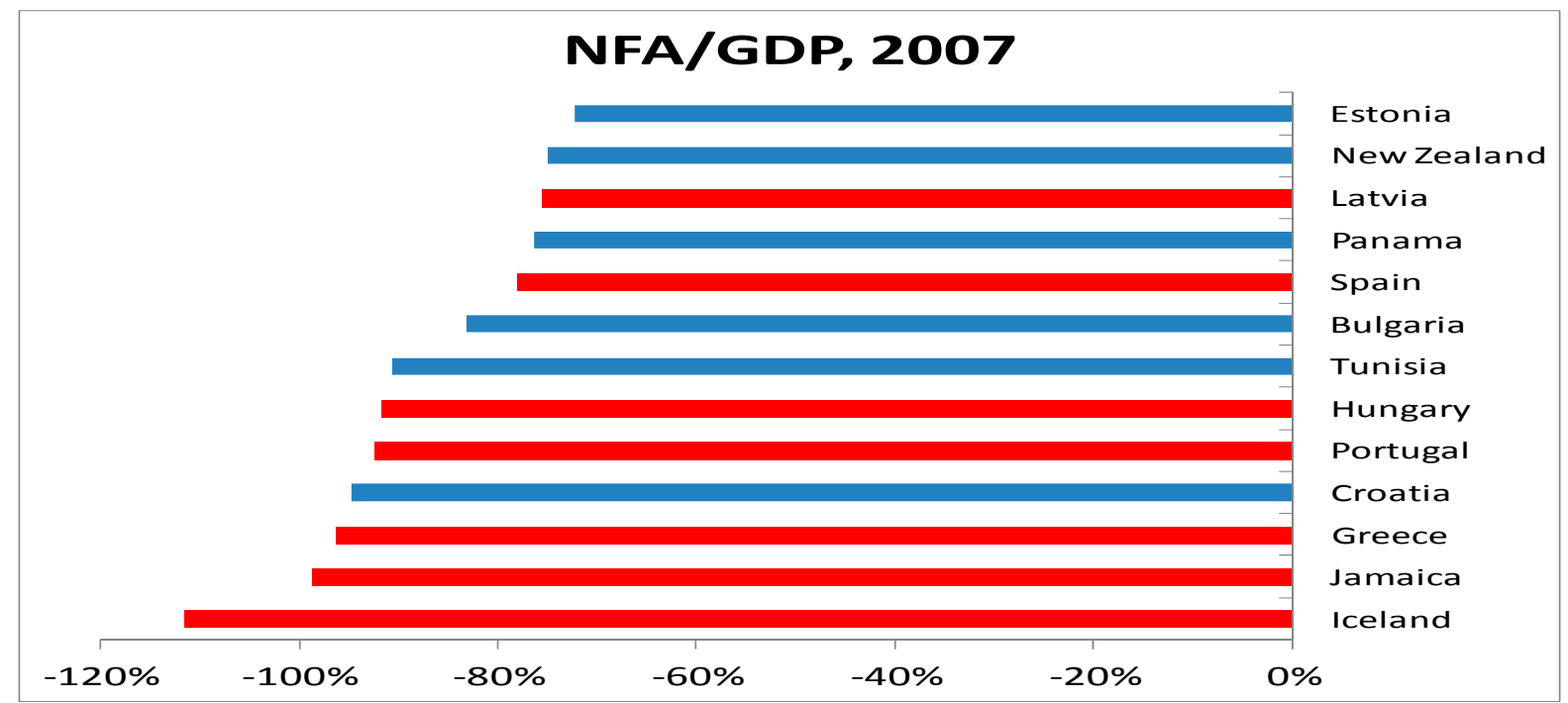

Against this background, we seek to answer three questions. The first is whether we can identify a proximate threshold beyond which any further build-up of net external liabilities sharply raises the risk of external crises. We measure the significance of this threshold relative to absolute (cross-country) levels, as well as to country-specific levels, using a treatment effect model with country and time effects. Establishing whether external liabilities beyond certain levels appear to be particularly risky is a question with tangible implications for fiscal and macro-prudential policies at a national level, as such policies affect the current account and external liability build-up; more broadly, it is clearly a crucial issue for country insurance and risk assessment, and hence a key input to any debate on international financial architecture. Our aim is to sharpen existing evidence on such "tipping points".

The second question we address is whether the composition of external assets and liabilities matters for crisis risk. We focus strictly on external crises, which include external defaults and rescheduling events as well as the recourse to sizable multilateral financial support (IMF programs). Using an updated version of the Lane and Milesi-Ferretti (2007) dataset spanning 
1970-2011 we break down net external asset positions between debt, portfolio equity, and foreign direct investment, as well as between reserve and non-reserve assets, and examine the impact of each of these components on crisis risk. We also consider a similar breakdown of gross - rather than net-positions (see the discussion in Shin (2012)). Distinguishing these components of a country's external balance allows us to test whether countries with high debt liabilities are more vulnerable to external crises than those with non-debt liabilities, particularly foreign direct investment (FDI).

The third question we tackle is how an econometric model featuring these variables as well as a few other controls performs at predicting external crises. We do so in- and out-ofsample, focusing in particular on the predictive accuracy over the recent crisis. Critics of previous work on crisis early warning systems (EWS) pointed at their failure in predicting out of sample. We thus examine whether this criticism applies to a more focused definition of "crises" - comprising major external crises — and to a model featuring disaggregated NFL components and other controls that did not feature in those earlier studies.

The main findings are as follows. First, we find evidence that crisis risk increases sharply as net foreign liabilities (NFL) exceed 50 percent of GDP and whenever the NFL/GDP ratio rises some 20 percentage points above the country-specific historical mean. Second, crisis risk rises as the composition of NFL is tilted toward debt liabilities. In comparison, the effects of portfolio equity liabilities are more mixed and generally weaker, whereas higher FDI liabilities tend, if anything, to reduce crisis risk. Third, current account deficits have a higher predictive power than any other individual regressor in most specifications. This predictive power is in fact marginally higher for unconditional levels of the current account relative to deviations from a model-based current account "norm" using standard specifications of that latter. Fourth, higher foreign exchange reserves reduce crisis risk by more than other asset holdings, in line with the results of Obstfeld et al., (2010) on the rationale for holding reserves as a precautionary/crisis prevention device. Finally, a multivariate but reasonably parsimonious probit model including all these controls has substantial predictive power, in and out of sample — particularly regarding the 2008-2011 crises. Also importantly, we find that many other variables featured in the previous literature on explaining crises do not add significant explanatory and predictive power.

These results speak to a large body of work on crisis early warning, current account and debt sustainability, as well as on country risk and sovereign default. Relative to work on early warning crisis systems (Frankel and Rose, 1995; Eichengreen et al., 1996; Kaminsky, Lizondo, and Reinhart, 1997; Kaminsky and Reinhart, 1999; Berg and Pattillo, 1999; Abiad, 2003), the main contribution of this paper lies in the use of a novel set of controls centered on net foreign assets and their composition, the availability of a longer sample on both the timeseries and cross-sectional dimensions, and the focus on external crises "stricto sensu". This allows us to probe into whether the poorer out of sample performance of earlier models were partly due to the choice of the dependent variable (currency/domestic financial crises there vs. large external crises here), as well as of independent variables and associated data limitations (e.g. disaggregated NFA data was not available at that time). Using longer time series data than previous work also allows us to establish whether a higher weight on the crisis events of the late 1990s played a role. In focusing on the out-of-sample predictive 
performance on the post-2007 crises, this paper is closely related to Frankel and Saravelos (2012), who look at which variables highlighted in the pre-2007 EWC literature deliver the strongest signals in terms of predictive power over post-2007 events. Like us, they find that external debt levels are significant; yet they also find that reserves and real exchange rate gaps are the most robust predictors of the post-2007 crises. In comparison, our analysis suggests the predictive power of these two variables is significantly higher when combined with others, and that the current account is the most powerful predictor of all.

Our paper is also related to a sizeable literature on external sustainability and the risk of sudden stops (Calvo, 1998; Milesi-Ferretti and Razin, 2000; Calvo et al., 2004; Edwards, 2004; Kraay and Nehru, 2006; Aguiar and Gopinath, 2006; Pistelli et. al., 2008; Gourinchas and Obstfeld, 2012; Jorda et al., 2012). A main distinction between Kraay and Nehru (2006) and Pistelli et al. (2008) and our work is that we focus on both emerging markets and advanced countries, rather than exclusively on the former. In relation to the work on external sustainability and sudden stops, we focus on a crisis definition centered on major external credit events - typically a subset of sudden stop occurrences. Our analysis of external liability thresholds in crisis risk is closely related to the treatment effects model in Gourinchas and Obstfeld (2012). The main difference lies in our definition of external crisis, the use of a wider set of controls, and the model selection criterion (ROC analysis and extensive out-of-sample predictive criteria).

Finally, our finding that NFL composition matters and that their effect on crisis risk is strongest for the debt liability component is consistent with standard models of sovereign debt, which have long focused on the ratio of external debt liabilities to GDP as a key gauge of default risk (Eaton and Gersovitz, 1981; Sachs and Cohen, 1985; Wright, 2006; Arellano, 2008; Catão, Fostel and Kapur, 2009; Panizza et. al., 2009; Mendoza and Yue, 2012). We corroborate the robustness of this wisdom on the basis of a broader sample and wider set of controls. This includes a finer breakdown of foreign assets and liabilities that did not feature in the earlier sovereign debt literature.

The paper is organized as follows. Section II presents our external crisis definition and data sample. Section III discusses the dynamics of NFL and its components in the run-up to external crises in Section III. We then identify thresholds above which crisis risk increases rapidly and use treatment effect regressions to ask whether pre-crisis dynamics of key variables are significantly distinct from behavior in normal times. Section IV examines the joint predictive power using the ROC approach to pick the "best" combination of a large set of variables and probes into out-of-sample predictive power. Section V concludes.

\section{Crisis Definition ANd DAta}

Our initial sample consists of 70 countries (of which 41 are emerging markets) spanning 1970-2011. ${ }^{2}$ To facilitate comparability of regression results across distinct specifications, we

\footnotetext{
${ }^{2}$ In eliminating lower income countries, we are deliberately leaving aside a myriad of smaller crises and countries where borrowing is mainly official and/or on a concessional basis rather than market driven. There are three main advantages of doing so. One is that the causal mechanisms developed in the theoretical literature on
}

(continued...) 
eliminate observations for which data on NFA or its breakdown into equity and debt are problematic. Specifically, we drop Ireland because a debt/equity breakdown is heavily distorted by its sizable mutual fund industry, whose liabilities are statistically recorded as equity instruments but whose assets include both equity and debt instruments. We also drop Iceland after 2000 because of extremely large swings in NFL, jumping from around 110 percent in 2007 to close to 700 percent of GDP at end-2008, which would leverage our results. ${ }^{3}$ The final country list is shown in Appendix I.

As mentioned above, our baseline definition of external crises encompasses defaults and rescheduling events (as per the definition of Bein and Calomiris (2001) and Standard \& Poors, as compiled in Borensztein and Panizza, 2008, and updated by us) as well as events associated with resort to large multilateral/IMF support. Large multilateral support is herewith defined as IMF loans that are at least twice as large as the respective country's quota in the IMF, when all net disbursements are computed from program's inception to end.

A hallmark of this crisis definition is that it focuses on major external crisis events. Another distinctive feature vis-à-vis previous work is that we treat these events as discrete, watershedlike occurrences: we exclude from our sample observations that are ramifications of the initial major crisis outbreak, all the way up to the year preceding market re-entry. As an illustration, take a country that defaulted in 1983 and had a non-trivial share of its debt stock in arrears up to market re-entry following the completion of the respective Brady deal in, say, 1992. In that case, we do not treat credit events associated with partial repayments and partial defaults/re-schedulings (the so-called muddling-through) in the interim period as separate events. While the downside is to leave us with a smaller number of default observations than often found in other studies, this is consistent with the conception of debt crises as major events of long-lasting consequences; and those big-bangs are the events that are systemically important to predict. In addition, excluding country/year observations that lie between the initial default and market re-entry has two advantages; one is to mitigate estimation biases arising from feedback effects of the crisis onto the explanatory variables, as discussed in Bussière and Fratzscher (2006); the other is to make crises more comparable as it eliminates a large number of smaller credit events. We define market re-entry as either the year after S\&P classifies the default to have ended or-when the crisis categorization does not involve default but a large IMF loan—when the country's liabilities vis-à-vis the IMF are either brought down to below 200 percent of quota or, if remaining above 200 percent, decline by two consecutive years. We prefer this procedure for treating market exclusion spells to the one adopted by Gourinchas and Obtsfeld (2012) who, instead, drop all observations within 4-

country borrowing require some reasonable degree of country integration with international capital markets, so we can draw on that literature to derive clear-cut testable implications and choice of co-variates. Second, we circumvent data limitations typically more prevalent in poorer countries and could potentially undermine confidence in the results. Last but not least, focusing on major crises stacks the deck against finding a trivially lower threshold to foreign liability exposure.

${ }^{3}$ Because these are countries that experienced external crises as per our definition in 2008 and 2010 respectively, our sample would otherwise comprise 63 events. Note, of course, that both countries had large and increasing net external liabilities and experienced crises. 
years after default regardless of whether market re-entry may be longer or shorter. In several crises, notably those of the 1980 s, full market re-entry took much longer than four years.

On this basis, our baseline sample has close to 2000 observations and 61 crisis events, implying an unconditional probability of crisis of 3 percent. Figure 2 plots the sample distribution of external crises. A list of all crisis episodes (broken down by default/rescheduling and large IMF lending) is also provided in Appendix 1.

Figure 2. Sample Distribution of External Crises

(number of crisis per year)

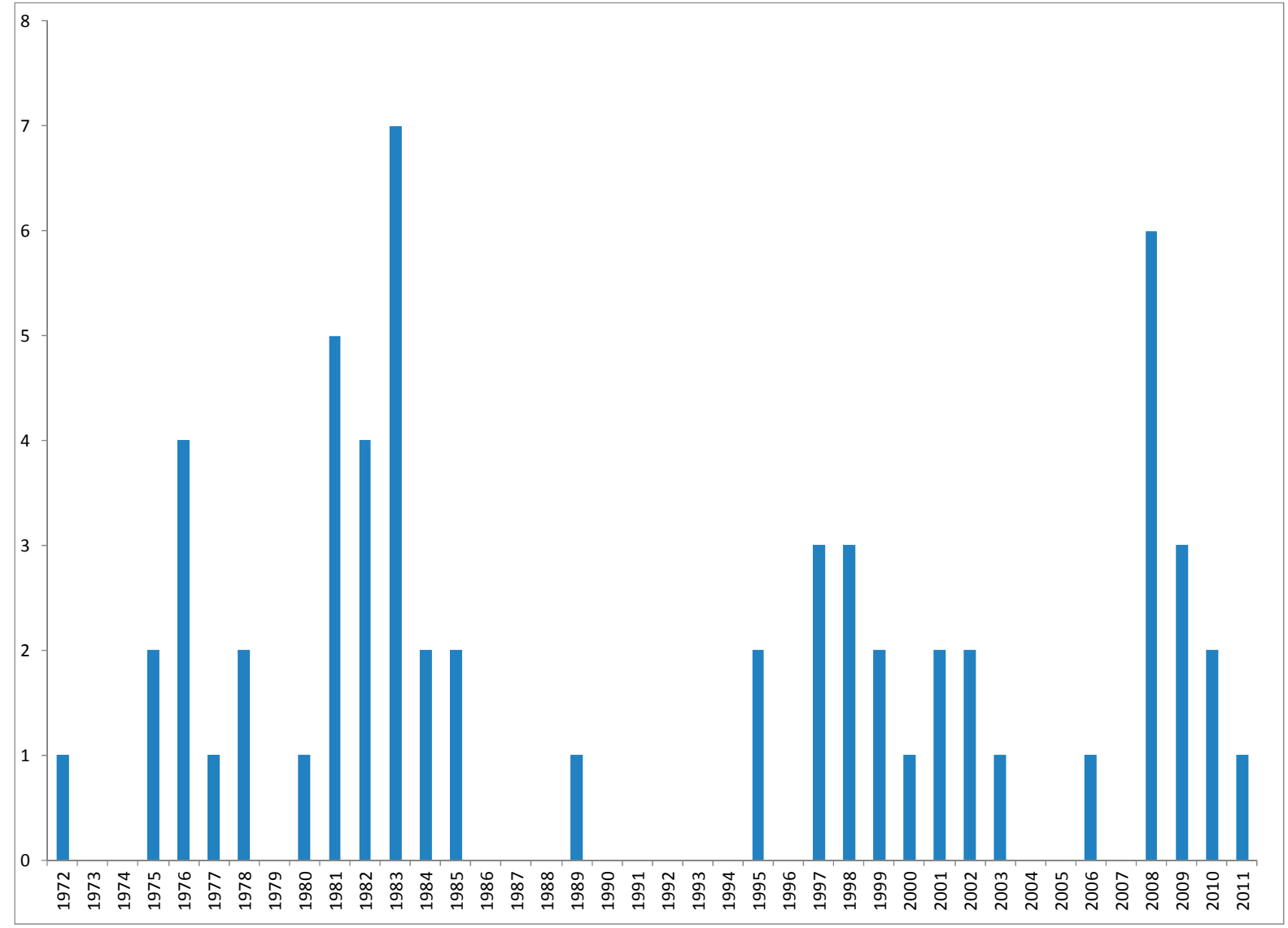

\section{Crisis Dynamics AND MODEL-Free Threshold EstimateS}

We start by examining the pre- and post-crisis dynamics of a few variables that are most relevant for crisis risk. Subsequent analysis in Section IV will corroborate this choice. Conditional on it, we proceed in two steps. First, we perform a standard event analysis in which observations for the variable in question are averaged over each external crisis episodes (often more than one crisis per country). We compute such averages over a 11-year 
window centered on the crisis year $(\mathrm{t}=0)$ and spanning 5 years prior and after the crisis. Since we are also interested in predictive power using past information, we also ask whether the recent (post-2007) crises have been any different in that regard. Second, we look at statistical significance controlling for fixed and time effects. This enables us to gauge what are levels of exposure appear riskier relative to the country's own historical mean net of time effects.

Figure 3 presents the unconditional evolution of the cross-country mean (over the 61 crisis episodes in our sample) of each of the variables of interest. Starting with NFL, it appears that they pose a crisis risk when they are in the 50 to 60 percent of GDP range. The first panel of Figure 3 also suggests that recent crises have occurred at higher NFL levels, with such a threshold closer to 60 percent. The subsequent four panels in Figure 2 disaggregate NFL, showing that the deterioration of the net foreign debt position (defined as the difference between debt assets - portfolio debt securities, other investment, and foreign exchange (FX) reserves - and debt liabilities) is typically sizeable in the run-up to crises; and that this deterioration is of a similar magnitude between pre- and post-2007 crises. ${ }^{4}$ The (unconditional) dynamics of the net portfolio equity position, net foreign direct investment (FDI) position, and foreign exchange reserves are more mixed. In the case of portfolio equity, one observes a mild worsening in pre-2007 crises, but not in post-2007 episodes: the global stock market boom of 2004-2007 drove sharply up the value of such assets relative to others. Regarding FDI, the sharp difference in levels comes from the fact that the net recourse to FDI financing has increased very sharply over the past two decades, particularly in Central and Eastern Europe. But again, unlike debt, the deterioration in the net FDI position in the run-up to crisis is modest. Similar considerations apply to reserves. In contrast, current account behavior is conspicuous: both pre- and post-2007, crisis-stricken countries start off with current account deficits of around 4 percent of GDP; from then, the current account deteriorates further until the eve of the crisis before turning sharply around. This is well-known from the large literature on current account reversals and sudden stops (Milesi-Ferretti and Razin, 2000; Calvo et al, 2004). Our analysis simply corroborates this stylized fact for a more up-to-date sample and focused definition of external crises, and provides newer estimates of the magnitudes.

\footnotetext{
${ }^{4}$ As shown in section IV, our regression results indicate that net rather than gross external debt is the more relevant metric for crisis risk. Accordingly, our threshold analysis focuses on net rather than gross external debt.
} 
Figure 3. Unconditional Means of Selected Variables Around External Crises
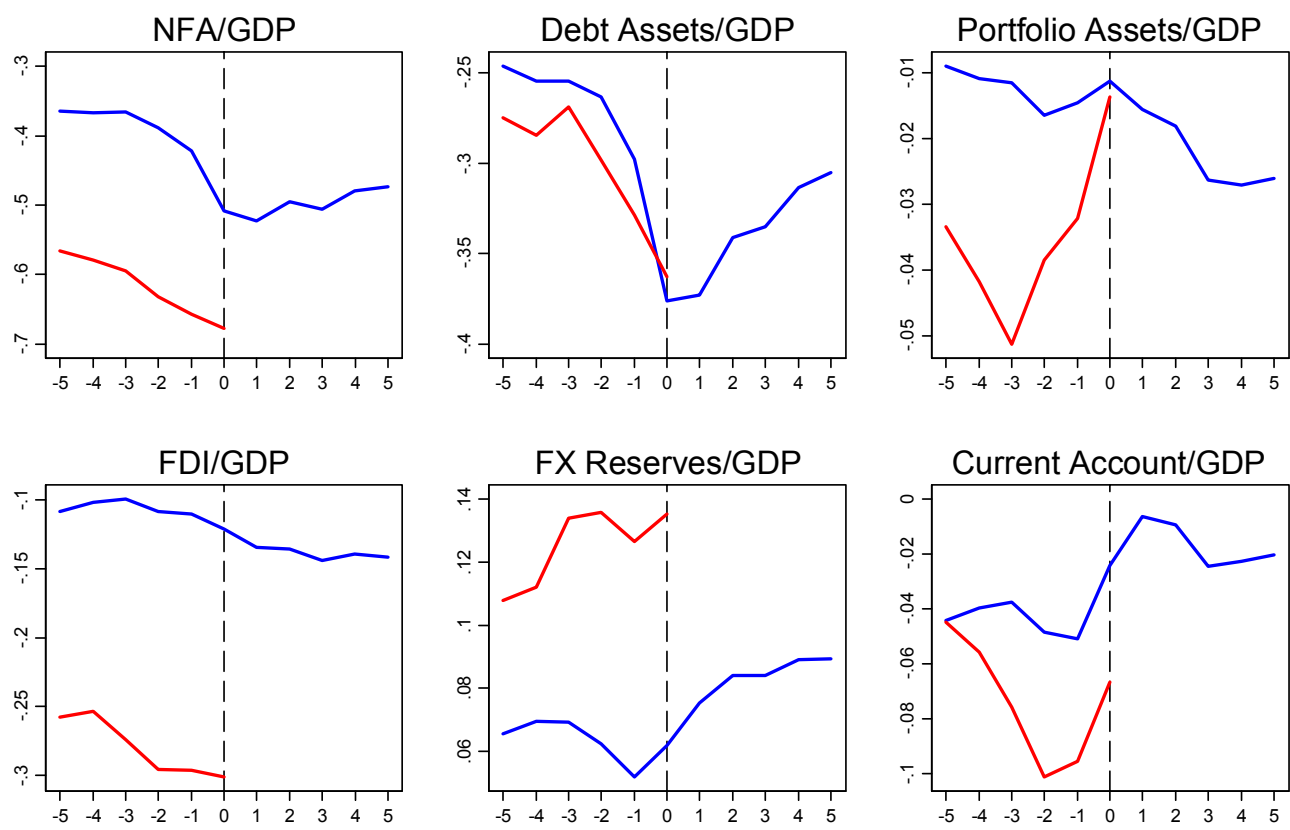

Mean pre-2007 crises

Mean post-2007 crises
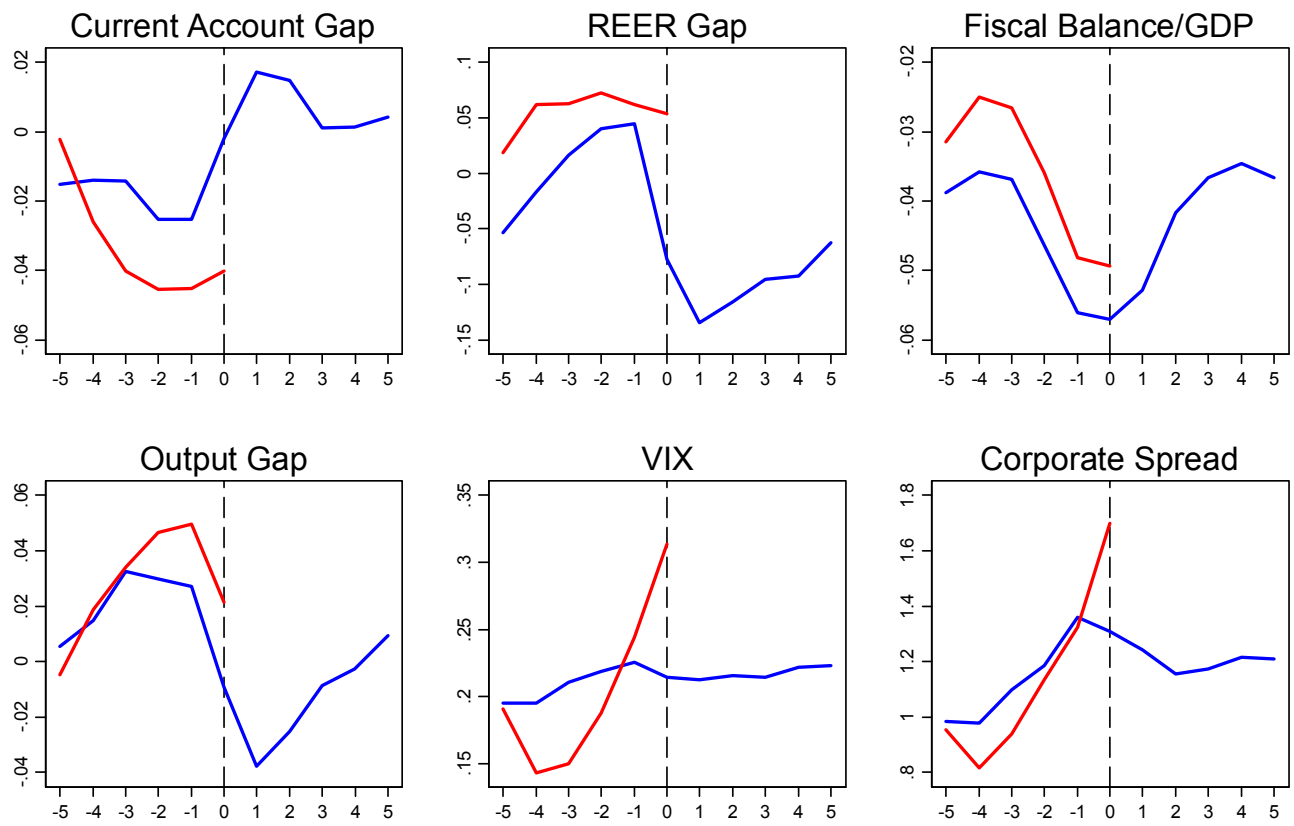
Figure 3 also looks at other pertinent variables, three of which (the real exchange rate, the fiscal balance and the output gap) featured prominently in early studies of early warning indicators and crisis risk (see Berg and Pattillo, 1999, and Frankel and Saravelos, 2012 for useful surveys). The first of these additional variables is the current account "gap", computed as the residual of a regression of the current account on its medium-term determinants, following closely the specifications in Lee and al (2008) and IMF (2012), once cyclical and other shorter-term influences are factored out (see Appendix II). The time pattern is very similar as that of the unconditional current account balance in Figure 1, except that levels are much less negative, particularly for the post-2007 sub-sample. The second is the real effective exchange rate (REER) "gap" - computed as the deviation of current REER levels to its 5-year moving average. Large real exchange rate appreciations can eventually trigger an economically painful reversal due to un-hedged balance sheet positions as in sudden stop models à la Calvo (1998). The REER gap shows a familiar pre-crisis pattern: an appreciation in the run-up to the crisis, followed by a depreciation (of nearly 20 percent from peak to trough). The dynamics of the fiscal balance (cyclically adjusted) and the output gap are familiar reasonably similar between pre- and post-2007 events.

Finally, the time clustering of crises highlighted in Figure 3 suggests that global factors are important. The last two panels of Figure 3 focus on two indicators of global financial conditions that have been emphasized in recent work - namely, global stock market volatility (proxied by the VIX index) and the interest rate spread between AAA- and BAA- rated U.S. corporates. Neither of those indicators featured in the previous literature on early warning crisis models, but they seem to be relevant as common triggering factors. Given that the post2007 external crises were mostly triggered by financial factors, it is not surprising the tightening of both financial condition indicators was particularly sharp for that sub-sample.

One criticism of inferences based on Figure 3 is that, because these are averages over crisis events only, they do not gauge the statistical significance of differential behavior between "crisis" and "tranquil" times. We address this concern by using a treatment-effect regression similar to that proposed in Gourinchas and Obstfeld (2012): ${ }^{5}$

\footnotetext{
${ }^{5}$ This specification bears three differences relative to the one implemented by Gourinchas and Obstfeld (2012). One is that it allows for a time (year) effect throughout. As we shall see later, this seems important since crosscountry time-varying factors associated with the global business cycle and global financial markets volatility can bear a significant causal connection with crisis risk. For the case of variables that (if accurately measured) should globally add to up zero at any point of time (such as NFA and the current account), keeping the time effect control might still be important since our regressions are not GDP weighted, so $\sum y_{i_{t}}$ may be far away from zero. The other difference is that their specification also includes dummies for currency and systemic banking crises. However, they find that allowing for interaction effects with other types crises does not significantly affect the coefficients of interest. Accordingly, they end up with a specification that eliminates these interaction effects. The third difference is that they estimate their version of equation (1) separately for advanced and emerging countries. We consider that the anatomy of external crisis bears sufficient cross-country similarities, particularly for recent crises.
} 


$$
y_{i_{t}}=\alpha_{i}+\sum_{t=1}^{T-1} \lambda_{t} D_{t}+\sum_{s=-5}^{5} \beta_{s} D_{s}+\varepsilon_{i_{t}}
$$

where the $\beta_{s}$ coefficients measure how proximity to a crisis changes the behavior of variable $y$ within an 11-year window center on the year of the crisis outbreak. Because the first two terms on right of (1) capture country-specific and global (time) effects, the coefficients $\beta_{s}$ gauge how much a rise/fall in the variable affect crisis risk, relative to the country-specific as well as the global mean. So, this metric provides a complementary gauge to those of Figure 3 based on the "untreated" or absolute mean.

Figure 4 plots the estimates of $\beta_{s}$ for each $y$ together with the respective 2 standard error bands. The first panel shows that external crises have been typically associated with NFA/GDP ratios between 15 and 20 percent below mean and declining in the run-up to crisis. The respective tolerance bands in dotted lines indicate that these effects are statistically significant at 5 percent. The subsequent three panels indicate that this effect is basically due to debt accumulation: crises are significantly associated with a reduction in net debt assets between 15 to 20 percent of GDP on average. The results for FX reserves and the current account are likewise strong: crises tend to occur in countries with reserves lower than the mean by 2 percent of GDP or so and with current account deficits around 3 percent of GDP larger than the country specific/global mean and deteriorating. The remaining panels in Figure 4 basically corroborate the evidence of the unconditional means of Figure 3: real exchange rate appreciations, rising fiscal deficits, and global financial market volatility are significant precursors of external crises. 
Figure 4. Conditional Mean of Selected Variables Around Crises (Treated by Fixed and Time Effects)
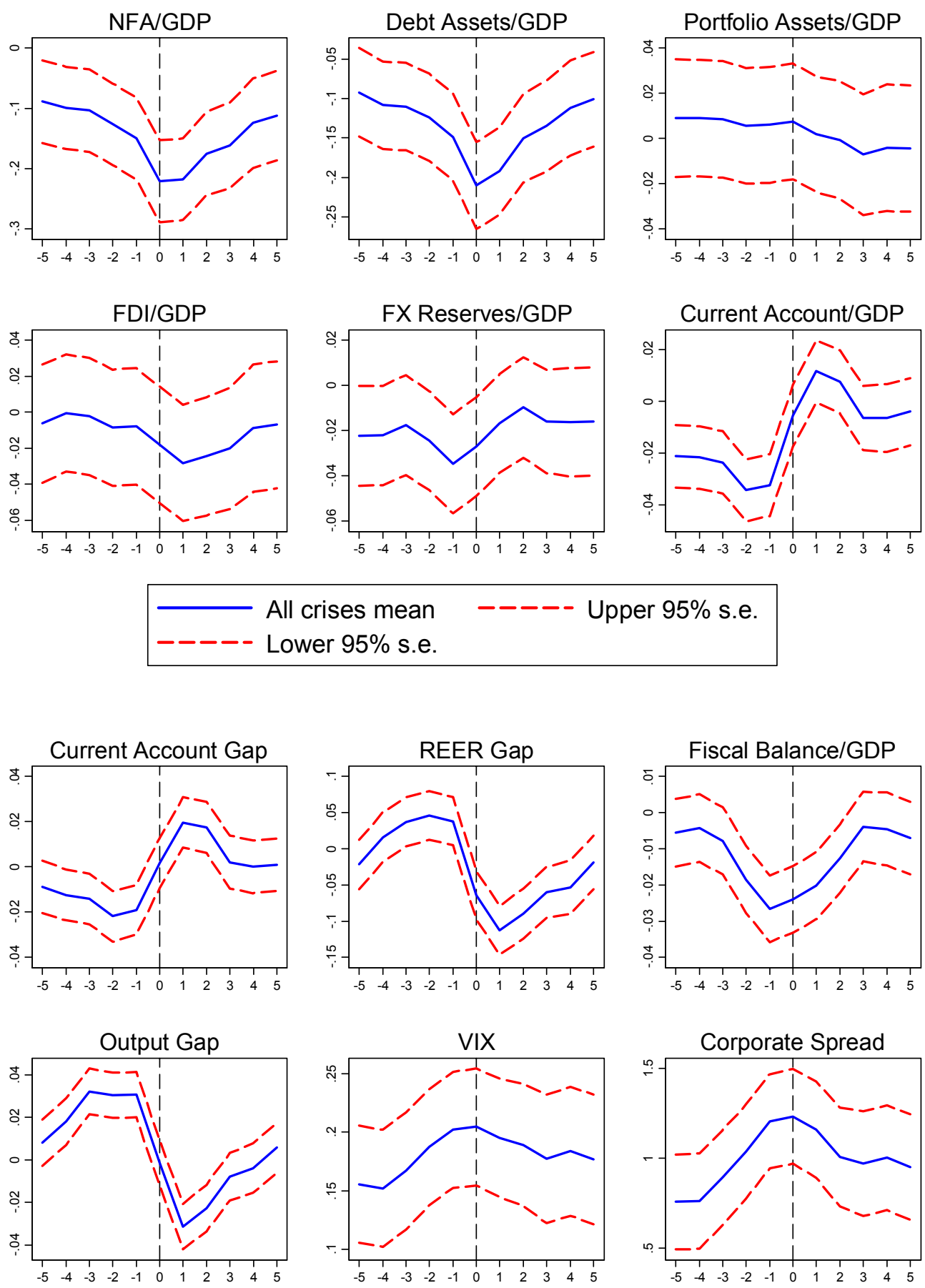

$$
\begin{aligned}
& \text { All crises mean } \quad----- \text { Upper } 95 \% \text { s.e. } \\
& \text { Lower } 95 \% \text { s.e. }
\end{aligned}
$$




\section{CRISIS MODEL}

\section{A. Model Selection Criterion}

We now turn to the question of how far NFL positions and their composition matter in determining crisis probabilities in a broad multivariate context. We build a multivariate probit/logit model that is reasonably parsimonious but also robust enough to retain considerable predictive power out of sample, and ask how such model would fare if asked to predict the recent crises of 2008-2011 when estimated on data up to 2006.

We use the receiver operating characteristic (ROC) curve as a model selection tool. The ROC curve plots the fraction of true positives (crisis=1) that a given model signals (out of all positives in the sample) vs. the fraction of false positive signals (out of all negatives in the sample) along contiguous threshold settings. The best model according to this criterion is the one that delivers the highest trade-off frontier between true and false alarms. Within that frontier, the analyst can choose — based on his/her utility - a threshold A in which a probit/logit estimated value $\mathrm{p}>\mathrm{A}$ is interpreted as a crisis signal. Such a threshold choice will be guided by the relative cost of failing to predict a crisis vs. that of calling a crisis when it turns out not to materialize (credibility cost). But provided that such a choice is along the ROC curve, the trade-off cannot be improved upon. A clear advantage of this approach over model/variable selection criteria previously used in the EWS literature is that the analyst does not have to take a stand a priori on which region of the trade-off to pick (e.g. minimizing noise to signal ratios or minimizing missed good calls at any cost): distinct models deliver a distinct ROC curve and the overall "best" is the one that delivers the highest area under the curve, i.e., the higher outward frontier above the 45 degree line, where the latter traces out the good vs. false positive trade-off under random guesses. Recent applications of the ROC curve methodology to historical data on domestic bank credit in 14 advanced countries are provided in Schularick and Taylor (2012) and Jordá, Schularick, and Taylor (2012), whereas Satchell and Wei (2006) present an earlier application to credit rating models. Yet, we are not aware of its use in the context of external crisis models.

\section{B. Estimates}

We construct ROC curves for a probit where crisis=1 during the year of the external crisis outbreak and crisis $=0$ during normal times. ${ }^{6}$ For the reasons discussed in Section II, we drop from the sample the years subsequent to the crisis outbreak up to the point when the country re-establishes market access (defined as in Section II). All explanatory variables are lagged one year so as to mitigate endogeneity biases.

We start with plotting the ROC curve for the bi-variate relationship between crisis probability and (lagged) NFA to GDP. Figure 5 adds to the standard bi-dimensional ROC curve a third axis measuring NFA/GDP. Clearly, even a rather stripped-down probit with lagged NFA/GDP as the only explanatory variable does much better than random guessing

\footnotetext{
${ }^{6}$ Using a logit instead of a probit specification is immaterial to our inferences.
} 
crisis risk, as the area under the ROC curve is substantial at 0.73 (Table 1). This is actually marginally higher predictive power than that obtained by Schularick and Taylor (2012, Figure 6) on domestic credit crisis using a fuller specification and spanning a much more homogenous country sample, consisting only of a handful of advanced economies. Moving along the ROC curve in Figure 5, one can glean the trade-offs of setting NFA/GDP thresholds which are "risky": For highly negative NFA (in excess of -100 percent of GDP), the likelihood of a false alarm is trivial; conversely for highly positive NFAs (in excess of 100 percent of GDP), which in our sample corresponds to financial centers like Hong Kong S.A.R. of China, Switzerland, and Singapore. ${ }^{7}$ The indifference point between the two errors is given by the point in the curve at 90 degrees of the non-discrimination ( 45 degree) line. At that point, NFA is about -20 percent of GDP and, as a result, a large share of false alarms (just under 50 percent) is generated. As NFA enters positive territory and approaches extreme positive values, any chosen threshold in that range of the ROC curve will entail no missed calls (as no crises in our sample have been associated with positive NFA); yet, such an aggressive threshold would entail an even higher share of false alarms. As discussed below, we shall focus on the threshold given by the point where the signal to noise ratio is maximized, i.e., where the ROC curve is steepest.

\section{Figure 5. ROC curve for NFA only model}

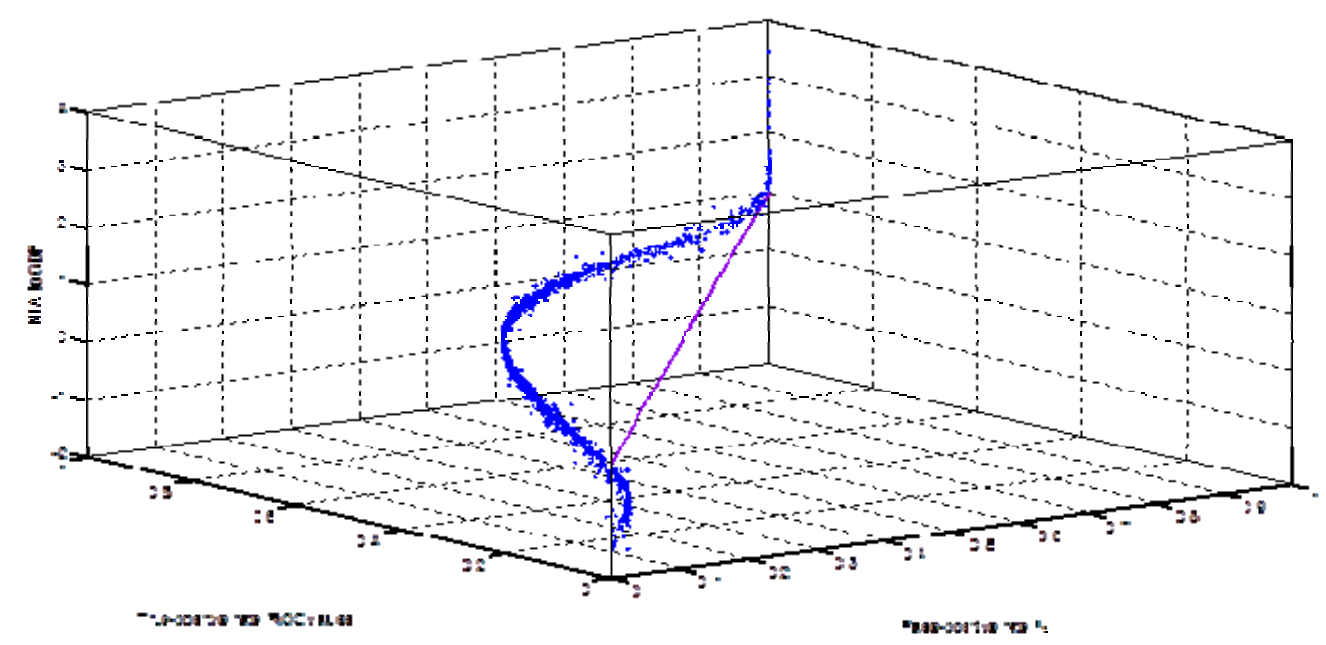

Table 1 shows how disaggregating NFA into debt and equity components improves model performance. Specifically, the area under the ROC curve (AUROC) rises to 0.75 from 0.73 . Adding reserves separately, inches this up to 0.76 . In itself, this is respectable performance. The biggest marginal jumps in the ROC curve are, however, due to the inclusion of the lagged unconditional current account (2-year average) and per capita income relative to the US (PPP basis) to take into account the distinction between advanced and emerging

\footnotetext{
${ }^{7}$ In our sample, the panel-wide standard deviation of NFA/GDP is 48 percent, so a 2 standard deviation of NFA to GDP is about 100 percent.
} 
countries. Adding global financial volatility (proxied by the VIX) as well as REER and fiscal gaps provide additional, even if smaller gains. Overall, this parsimonious model yields an AUROC of 0.90 .

Table 1. AUROC Estimates for Various Model Specifications

1) NFA only:

2) Net Debt, Net Portfolio, FDI:

3) Adding Reserves:

4) Adding Per capita Income viz US:

5) Adding Current Account/GDP:

6) Adding REER gap:

7) Adding VIX

8) Adding Fiscal Balance Gap:
0.73

0.75

0.76

0.82

0.86

0.88

0.89

0.90

Table 2 reports the probit coefficients for each individual variable in the various specifications. ${ }^{8}$ As usual and consistent with previous work, variables enter the probit model lagged one year and robust standard errors are computed clustered at a country level. Consistent with above AUROC estimates, net debt, the current account balance, and per capita income are key drivers of crisis risk. The strong significance of the current account is consistent with existing studies that have found current account deficits to be a significant predictor of external crises using a variety of definitions of the latter (Milesi-Ferretti and Razin, 2000; Pistelli, Selaive, and Valdés, 2008). The inclusion of per capita income in turn has the important effect of making FX reserves holdings more significant as well as making the FDI coefficient less negative. This is not surprising, since richer countries typically have a much higher average share of FDI in GDP so the inclusion of per capita income controls for this quasi-fixed effect. More notably column (6) shows that the coefficient on FDI becomes positive and significant once the current account balance is included in the regression. That is, controlling for an increase in net liability exposure (as measured by the current account balance), higher net FDI liabilities thus tend to be associated with lower crisis risk. This is consistent with previous evidence that higher FDI liabilities are typically associated with improved economic prospects (Borezstein et al., 1998), help relax financing

\footnotetext{
${ }^{8}$ Because of missing FDI data for Jordan before 2000 has been entered as zero in the respective IIP series, those observations have been dummied out.
} 
constraints and are a safer form of external financing overall (Hausmann and FernandezArias, 2001) and- the so-called "good cholesterol" view of FDI liabilities.

Table 2. Baseline Crisis Definition: Probit Estimates

\begin{tabular}{|c|c|c|c|c|c|c|c|}
\hline VARIABLES & $\begin{array}{c}\text { (1) } \\
\text { crisis }\end{array}$ & $\begin{array}{c}(2) \\
\text { crisis }\end{array}$ & $\begin{array}{l}\text { (3) } \\
\text { crisis }\end{array}$ & $\begin{array}{c}\text { (4) } \\
\text { crisis }\end{array}$ & $\begin{array}{c}5) \\
\text { crisis }\end{array}$ & $\begin{array}{c}\text { (6) } \\
\text { crisis }\end{array}$ & $\begin{array}{c}7) \\
\text { crisis }\end{array}$ \\
\hline Net Foreign Assets/GDP & $\begin{array}{c}-0.990^{* * *} \\
(0.193)\end{array}$ & & & & & & \\
\hline Net external debt assets /GDP & & $\begin{array}{c}-1.750^{* * *} \\
(0.260)\end{array}$ & $\begin{array}{c}-1.579^{* * *} \\
(0.308)\end{array}$ & $\begin{array}{c}-1.662^{* * *} \\
(0.317)\end{array}$ & $\begin{array}{c}-0.987^{* *} \\
(0.436)\end{array}$ & $\begin{array}{c}-1.404^{* * *} \\
(0.460)\end{array}$ & $\begin{array}{l}-1.223^{* *} \\
(0.498)\end{array}$ \\
\hline Net external portfolio equity /GDP & & $\begin{array}{l}-0.156 \\
(0.416)\end{array}$ & $\begin{array}{l}-0.274 \\
(0.427)\end{array}$ & $\begin{array}{l}-0.0929 \\
(0.476)\end{array}$ & $\begin{array}{c}0.314 \\
(0.989)\end{array}$ & $\begin{array}{c}0.431 \\
(1.053)\end{array}$ & $\begin{array}{c}0.534 \\
(1.213)\end{array}$ \\
\hline Net Foreign Direct Investment/GDP & & $\begin{array}{l}-0.301 \\
(0.292)\end{array}$ & $\begin{array}{l}-0.572 \\
(0.384)\end{array}$ & $\begin{array}{l}-0.0497 \\
(0.385)\end{array}$ & $\begin{array}{l}0.676^{*} \\
(0.361)\end{array}$ & $\begin{array}{l}0.870^{* *} \\
(0.369)\end{array}$ & $\begin{array}{l}1.193^{* * *} \\
(0.412)\end{array}$ \\
\hline FX reserves/GDP & & & $\begin{array}{l}-2.200^{*} \\
(1.156)\end{array}$ & $\begin{array}{c}-2.828^{* *} \\
(1.117)\end{array}$ & $\begin{array}{c}-3.230^{* * *} \\
(1.199)\end{array}$ & $\begin{array}{c}-3.704^{* * *} \\
(1.273)\end{array}$ & $\begin{array}{c}-3.984^{* * *} \\
(1.424)\end{array}$ \\
\hline Relative Per Capita Income & & & & $\begin{array}{c}-1.497^{* * *} \\
(0.256)\end{array}$ & $\begin{array}{c}-1.602^{* * *} \\
(0.268)\end{array}$ & $\begin{array}{c}-1.905^{* * *} \\
(0.304)\end{array}$ & $\begin{array}{c}-2.294^{* * *} \\
(0.359)\end{array}$ \\
\hline CA balance/GDP (2-year MA) & & & & & $\begin{array}{c}-8.492^{* * *} \\
(1.950)\end{array}$ & $\begin{array}{c}-7.684^{* \star *} \\
(1.901)\end{array}$ & $\begin{array}{c}-10.40^{* * *} \\
(2.439)\end{array}$ \\
\hline REER gap & & & & & & $\begin{array}{c}2.105^{\star * *} \\
(0.440)\end{array}$ & $\begin{array}{l}2.001^{* * *} \\
(0.468)\end{array}$ \\
\hline VIX & & & & & & $\begin{array}{l}0.734^{* * *} \\
(0.233)\end{array}$ & $\begin{array}{l}0.697^{* \star *} \\
(0.250)\end{array}$ \\
\hline Fiscal Gap & & & & & & & $\begin{array}{c}-5.069^{* *} \\
(2.505)\end{array}$ \\
\hline Observations & 2,042 & 2,042 & 2,042 & 2,042 & 2,042 & 2,042 & 1,832 \\
\hline Pseudo R-squared & 0.07 & 0.09 & 0.10 & 0.17 & 0.21 & 0.26 & 0.31 \\
\hline
\end{tabular}

Robust standard errors in parentheses

*** $p<0.01,{ }^{* *} p<0.05,{ }^{*} p<0.1$

Also consistent with priors as well as with the evidence presented in Figures 3 and 4, all relative price and global variables are statistically significant. Finally, column (7) indicates that the addition of the fiscal gap (like the REER gap, measured as the general government balance in the given year relative to its five-year moving average) further contributes to crisis risk. In doing so, as one might expect, it reduces somewhat the net external debt and current account coefficients and, yet, both remain highly significant economically and statistically.

Table 3 reports the marginal effects of our final specification in column 6 of Table 2 . Because crises are rare events, elasticities appear to be low when computed at the sample mean. However, the non-linearity of the probit specification implies that these elasticities can be substantial when computed at crisis proximity points. The third and fourth column of Table 3 provide two alternative elasticity measures: in the year before a crisis actually materializes, and when crisis probability is higher than 10 percent. Both measures indicate 
that the elasticity of crisis risk to changes in the covariates can be substantial. For instance, one standard deviation increase in net external debt to GDP (a 20 percentage point rise) raises the probability of external crises by over 6 percent, while a one standard deviation in current account deficit adds some 10 percent to crisis risk. The estimates also suggest an important role for reserve accumulation as a crisis precaution device: an increase in central bank reserves of 7 percent of GDP - the sample standard deviation and a magnitude not far off that observed in some emerging markets over the past decade-reduces crisis risk by some 7 percent (leaving the net debt position unchanged).

Table 3. Elasticity Estimates for Favored Specification

\begin{tabular}{|c|c|c|c|c|}
\hline & \multirow[b]{2}{*}{$\mathrm{SD}^{1 /}$} & \multicolumn{3}{|c|}{$\mathrm{dP} / \mathrm{dx}$} \\
\hline & & At mean & $\begin{array}{c}\text { year prior } \\
\text { to crisis }\end{array}$ & when $P>0.1$ \\
\hline Net external debt assets/GDP & 0.20 & -0.008 & -0.28 & -0.32 \\
\hline Net external portfolio equity/GDP & 0.10 & 0.004 & 0.12 & 0.14 \\
\hline Net Foreign Direct Investment/GDP & 0.11 & 0.008 & 0.27 & 0.32 \\
\hline FX reserves/GDP & 0.07 & -0.027 & -0.91 & -1.05 \\
\hline CA balance/GDP (2-year MA) & 0.04 & -0.072 & -2.37 & -2.75 \\
\hline Relative Per Capita Income & 0.06 & -0.016 & -0.52 & -0.61 \\
\hline REER gap & 0.12 & 0.014 & 0.46 & 0.53 \\
\hline $\mathrm{VIX}$ & 0.29 & 0.005 & 0.16 & 0.18 \\
\hline Fiscal Gap & 0.03 & -0.035 & -1.16 & -1.34 \\
\hline
\end{tabular}

1/ Computed from a pooled regression with fixed effects for each variable.

\section{Model-Based Threshold Estimates}

On the basis of the above model, we revisit the issue of identifying crisis risk thresholds. All what is needed to pin down the respective tipping points for the various model variables is to combine the above model with the choice of point along the ROC curve. A criterion to select such a point that has been widely used in the EWS literature following the contributions of Lizondo, Kaminsky and Reinhart (1997) and Kaminsky and Reinhart (1998), is that of maximizing the signal to noise ratio, i.e., the ratio of true positive to false positives. This corresponds to point where the ROC curve is steepest (i.e. the first derivative is maximized). Using this criterion and a univariate probit of crisis on lagged NFA/GDP (column (1) of Table 2), we obtain a tipping point for NFA/GDP of $-49 \%$, as shown in Figure 6. 
Figure 6. Univariate Model: Threshold for NFA/GDP that Maximizes Signal to Noise

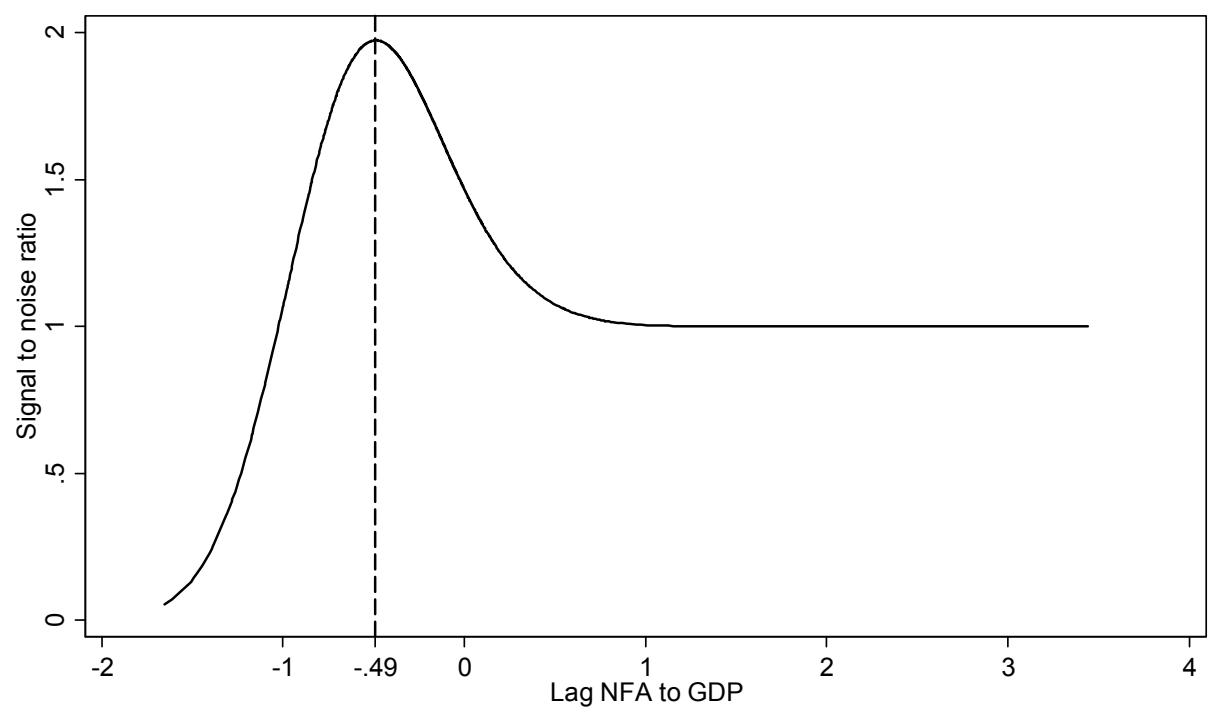

Accordingly, we can also compute the respective tipping points for each of the stock variables featuring in our baseline probit specification of column (7) in Table 2. These are reported in Table 4. As can be seen, the multivariate model delivers an estimate for the NFA/GDP threshold which is very similar to that of the univariate mode, around $-50 \%$. Breaking NFA down into its main components, we obtain a tipping point for net external debt liabilities around $35 \%$ of GDP. ${ }^{9}$

Table 4: Baseline Multivariate Model: Tipping Point Estimates

\begin{tabular}{|ccccc|}
\hline $\begin{array}{c}\text { Net Foreign } \\
\text { Assets/GDP }\end{array}$ & $\begin{array}{c}\text { Net Debt } \\
\text { Assets/GDP }\end{array}$ & $\begin{array}{c}\text { Net Portfolio } \\
\text { Assets/GDP }\end{array}$ & $\begin{array}{c}\text { Net FDI } \\
\text { Assets/GDP }\end{array}$ & $\begin{array}{c}\text { Net Reserve } \\
\text { Assets/GDP }\end{array}$ \\
\hline$-53 \%$ & $-35 \%$ & $0 \%$ & $-18 \%$ & $4.6 \%$ \\
\hline
\end{tabular}

\section{Robustness to Variable Omission}

To test the robustness of our favored specification to potential variable omission, we add to the regression a large selection of variables featured in previous work on crisis risk (see Frankel and Saravelos, 2012 for a comprehensive list). As always, all variables enter the regression one-year lagged and robust standard errors are clustered at a country level.

\footnotetext{
${ }^{9}$ While 35\% may appear substantially lower than the 60\% threshold reported in Reinhart and Rogoff (2010), note that the latter refer to gross external debt - therefore excluding all debt assets such as official foreign exchange reserves, privately-held debt securities, and foreign loans and deposits by residents. As we show below, our regression results indicate that net external debt is the significant indicator for crisis risk.
} 
The first column starts by adding the current account gap, defined as deviations of the current account from a fundamentals-based "norm" (see Appendix 2). The results indicate that this variable is highly collinear with the unconditional (2-year moving average) current account, but is dominated by the latter. While this may well be due to difficulties in estimating a true long-run "norm", it may also be because of the asymmetric effect that current account deviations from their "norm" has on crisis risk: countries with a positive current account balance may well have a current account gap (measured as in Appendix 2) which is negative; yet, a country with a negative current account gap and yet positive current account balance is typically much less vulnerable than a country that has the same negative CA gap and a negative actual CA balance. To the extent that the actual current account measure captures this asymmetry better, it can be a more precise indicator of crisis risk relative to the (estimated) CA gap.

Column (2) of Table 5 adds the ratio of general government debt to GDP to the baseline regression. While the external component of the latter is contained in the external debt variable, the introduction of that variable in the regression is a proximate control for the distinction between public and private external debt that have been documented as important to explain global imbalances, growth differentials, and hence (albeit indirectly) country risk (Alfaro et al. 2012). Yet, this yields the "wrong" sign and is highly imprecisely estimated. ${ }^{10}$ Further probing (by dropping some of the right hand side variables) indicates that this is due to colinearity with other controls already present in our favored specification. Indeed, once some other controls are dropped, the country's overall level of public debt becomes a significant determinant of crisis risk - as typically found to be the case in regressions on the determinants of sovereign spreads (see, e.g., Catão, Fostel and Kapur, 2009).

Other controls proved to be insignificant. Motivated by the results of Schularick and Taylor (2012), who find that credit growth is significant predictor of financial and growth crisis, column (3) adds the first difference of the credit to GDP ratio to our favored specification. Schularick and Taylor (2012) find that longer lags of credit growth work best, so we take a three-year moving average of lagged credit/GDP changes. The respective point estimate is insignificant and wrongly signed. Once again, further probing indicates that this is due to the effects of credit growth on crisis risk taking place via other controls already in the baseline specification: dropping all variables but relative per capita income, credit in excess

\footnotetext{
${ }^{10}$ The appropriate control for this regression is the net financial position of the government. However, measures of government financial assets are often unavailable on a systematic basis, especially for emerging markets. This measurement problem can also contribute to the lack of significance of the public debt variable.
} 
Table 5. Robustness to Other Controls

\begin{tabular}{|c|c|c|c|c|c|c|c|c|c|c|c|}
\hline VARIABLES & $\begin{array}{c}\text { (1) } \\
\text { crisis }\end{array}$ & $\begin{array}{c}\text { (2) } \\
\text { crisis } \\
\end{array}$ & $\begin{array}{c}\text { (3) } \\
\text { crisis } \\
\end{array}$ & $\begin{array}{c}\text { (4) } \\
\text { crisis } \\
\end{array}$ & $\begin{array}{c}\text { (6) } \\
\text { crisis } \\
\end{array}$ & $\begin{array}{c}(7) \\
\text { crisis } \\
\end{array}$ & $\begin{array}{c}\text { (8) } \\
\text { crisis } \\
\end{array}$ & $\begin{array}{c}\text { (9) } \\
\text { crisis }\end{array}$ & $\begin{array}{l}\text { (10) } \\
\text { crisis } \\
\end{array}$ & $\begin{array}{c}\text { (11) } \\
\text { crisis } \\
\end{array}$ & $\begin{array}{l}\text { (12) } \\
\text { crisis } \\
\end{array}$ \\
\hline Net external debt assets/GDP & $\begin{array}{l}-1.038 \\
(0.678)\end{array}$ & $\begin{array}{c}-1.314^{* *} \\
(0.516)\end{array}$ & $\begin{array}{c}-1.197^{* *} \\
(0.526)\end{array}$ & $\begin{array}{c}-1.221^{* *} \\
(0.501)\end{array}$ & $\begin{array}{c}-1.156^{* *} \\
(0.510)\end{array}$ & $\begin{array}{c}-1.160^{* *} \\
(0.475)\end{array}$ & $\begin{array}{c}-1.181^{* *} \\
(0.508)\end{array}$ & $\begin{array}{c}-1.247^{* *} \\
(0.487)\end{array}$ & $\begin{array}{c}-1.165^{* *} \\
(0.493)\end{array}$ & & $\begin{array}{c}-1.209^{* *} \\
(0.498)\end{array}$ \\
\hline Net external Porftolfio equity/GDP & $\begin{array}{l}1.184 \\
(1.192)\end{array}$ & $\begin{array}{c}0.285 \\
(1.200)\end{array}$ & $\begin{array}{c}0.459 \\
(1.207)\end{array}$ & $\begin{array}{c}0.287 \\
(1.168)\end{array}$ & $\begin{array}{c}0.519 \\
(1.229)\end{array}$ & $\begin{array}{c}0.517 \\
(1.274)\end{array}$ & $\begin{array}{c}0.580 \\
(1.176)\end{array}$ & $\begin{array}{c}0.583 \\
(1.165)\end{array}$ & $\begin{array}{c}0.603 \\
(1.129)\end{array}$ & $\begin{array}{c}0.483 \\
(1.237)\end{array}$ & $\begin{array}{c}0.452 \\
(1.272)\end{array}$ \\
\hline Net Foreign Direct Investment/GDP & $\begin{array}{l}1.145^{* *} \\
(0.572)\end{array}$ & $\begin{array}{l}1.222^{* * *} \\
(0.451)\end{array}$ & $\begin{array}{c}1.313^{* * *} \\
(0.427)\end{array}$ & $\begin{array}{l}1.153^{* * *} \\
(0.417)\end{array}$ & $\begin{array}{c}1.263^{* * *} \\
(0.401)\end{array}$ & $\begin{array}{c}1.267^{* * *} \\
(0.425)\end{array}$ & $\begin{array}{l}1.263^{* *} \\
(0.508)\end{array}$ & $\begin{array}{l}0.934^{* *} \\
(0.475)\end{array}$ & $\begin{array}{l}1.220^{* * *} \\
(0.411)\end{array}$ & $\begin{array}{l}1.067^{\star *} \\
(0.489)\end{array}$ & $\begin{array}{c}0.440 \\
(0.549)\end{array}$ \\
\hline FX reserves/GDP & $\begin{array}{l}-4.161^{* *} \\
(1.638)\end{array}$ & $\begin{array}{c}-3.347^{* *} \\
(1.428)\end{array}$ & $\begin{array}{c}-3.958^{\star * *} \\
(1.366)\end{array}$ & $\begin{array}{c}-3.589^{* * \star} \\
(1.369)\end{array}$ & $\begin{array}{c}-3.939^{* * *} \\
(1.454)\end{array}$ & $\begin{array}{c}-3.917^{\star \star \star} \\
(1.355)\end{array}$ & $\begin{array}{c}-4.090^{* * *} \\
(1.376)\end{array}$ & $\begin{array}{c}-3.470^{* * *} \\
(1.304)\end{array}$ & $\begin{array}{c}-3.752^{* * *} \\
(1.362)\end{array}$ & 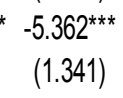 & $\begin{array}{c}-4.539^{* * *} \\
(1.445)\end{array}$ \\
\hline CA balance/GDP (2 year MA) & $\begin{array}{c}-11.09^{* *} \\
(5.232)\end{array}$ & $\begin{array}{c}-9.524^{* * *} \\
(2.398)\end{array}$ & $\begin{array}{c}-11.03^{* * *} \\
(2.807)\end{array}$ & $\begin{array}{c}-9.622^{* * *} \\
(2.474)\end{array}$ & $\begin{array}{c}-10.57^{\star * *} \\
(2.428)\end{array}$ & $\begin{array}{c}-10.41^{* * *} \\
(2.393)\end{array}$ & $\begin{array}{c}-10.63^{* * *} \\
(2.448)\end{array}$ & $\begin{array}{c}-10.07^{* * *} \\
(2.446)\end{array}$ & $\begin{array}{c}-10.00^{* * *} \\
(2.378)\end{array}$ & $\begin{array}{c}{ }^{*}-10.34^{* * *} \\
(2.446)\end{array}$ & $\begin{array}{c}-10.59^{* * *} \\
(2.365)\end{array}$ \\
\hline Relative Per Capita Income & $\begin{array}{c}-2.452^{\star * *} \\
(0.410)\end{array}$ & $\begin{array}{c}-2.307^{\star * *} \\
(0.375)\end{array}$ & $\begin{array}{c}-2.362^{* * *} \\
(0.365)\end{array}$ & $\begin{array}{c}-2.304^{* * *} \\
(0.359)\end{array}$ & $\begin{array}{c}-2.384^{* * *} \\
(0.385)\end{array}$ & $\begin{array}{c}-2.300^{* * *} \\
(0.362)\end{array}$ & $\begin{array}{c}-2.309^{* * *} \\
(0.372)\end{array}$ & $\begin{array}{c}-2.014^{* * *} \\
(0.384)\end{array}$ & $\begin{array}{c}-2.190^{* * *} \\
(0.377)\end{array}$ & $\begin{array}{c}-2.248^{* * *} \\
(0.376)\end{array}$ & $\begin{array}{c}-2.287^{* * *} \\
(0.374)\end{array}$ \\
\hline REER gap & $\begin{array}{c}2.389^{* * *} \\
(0.492)\end{array}$ & $\begin{array}{l}2.055^{\star * \star} \\
(0.452)\end{array}$ & $\begin{array}{l}2.173^{* * *} \\
(0.506)\end{array}$ & $\begin{array}{l}1.961^{* * *} \\
(0.471)\end{array}$ & $\begin{array}{l}1.885^{* * *} \\
(0.477)\end{array}$ & $\begin{array}{l}1.975^{* * \star} \\
(0.470)\end{array}$ & $\begin{array}{c}2.011^{* * *} \\
(0.495)\end{array}$ & $\begin{array}{c}2.223^{* * *} \\
(0.484)\end{array}$ & $\begin{array}{c}2.019^{* * *} \\
(0.453)\end{array}$ & $\begin{array}{l}1.985^{\star * *} \\
(0.474)\end{array}$ & $\begin{array}{l}1.921^{* * *} \\
(0.482)\end{array}$ \\
\hline VIX & $\begin{array}{c}0.920^{* * *} \\
(0.318)\end{array}$ & $\begin{array}{c}0.790^{\star * *} \\
(0.257)\end{array}$ & $\begin{array}{c}0.705^{\star * *} \\
(0.257)\end{array}$ & $\begin{array}{l}0.502^{*} \\
(0.286)\end{array}$ & $\begin{array}{c}0.688^{\star * *} \\
(0.250)\end{array}$ & $\begin{array}{c}0.683^{* * *} \\
(0.258)\end{array}$ & $\begin{array}{c}0.705^{\star * *} \\
(0.251)\end{array}$ & $\begin{array}{c}0.816^{* * *} \\
(0.274)\end{array}$ & $\begin{array}{c}0.752^{\star * *} \\
(0.248)\end{array}$ & $\begin{array}{c}0.700^{* * *} \\
(0.248)\end{array}$ & $\begin{array}{c}0.710^{* * *} \\
(0.244)\end{array}$ \\
\hline Fiscal Gap & $\begin{array}{l}-4.557 \\
(3.214)\end{array}$ & $\begin{array}{c}-5.850^{* *} \\
(2.610)\end{array}$ & $\begin{array}{l}-4.116 \\
(2.512)\end{array}$ & $\begin{array}{l}-4.638^{*} \\
(2.491)\end{array}$ & $\begin{array}{l}-4.788^{*} \\
(2.454)\end{array}$ & $\begin{array}{c}-5.168^{* *} \\
(2.548)\end{array}$ & $\begin{array}{l}-4.398^{\star} \\
(2.365)\end{array}$ & $\begin{array}{l}-5.149^{*} \\
(2.706)\end{array}$ & $\begin{array}{l}-5.514^{* *} \\
(2.528)\end{array}$ & $\begin{array}{c}-5.106^{* *} \\
(2.492)\end{array}$ & $\begin{array}{c}-5.208^{* *} \\
(2.527)\end{array}$ \\
\hline Current Account gap & $\begin{array}{c}0.134 \\
(4.853)\end{array}$ & & & & & & & & & & \\
\hline Overall Public Debt/GDP & & $\begin{array}{c}-0.325 \\
(0.274)\end{array}$ & & & & & & & & & \\
\hline Growth of Credit/GDP (3-year MA) & & & $\begin{array}{l}-1.175 \\
(1.829)\end{array}$ & & & & & & & & \\
\hline US Corporate Credit Spread & & & & $\begin{array}{c}0.265 \\
(0.191)\end{array}$ & & & & & & & \\
\hline Trend Output Growth & & & & & $\begin{array}{c}-2.947 \\
(4.245)\end{array}$ & & & & & & \\
\hline Foreign Exchange Regime & & & & & & $\begin{array}{l}-0.0551 \\
(0.0577)\end{array}$ & & & & & \\
\hline$(\mathrm{X}+\mathrm{M}) / \mathrm{GDP}(5$-year MA) & & & & & & & $\begin{array}{l}0.0977 \\
(0.680)\end{array}$ & & & & \\
\hline Capital Controls & & & & & & & & $\begin{array}{c}0.496 \\
(0.391)\end{array}$ & & & \\
\hline Institutional Quality (Polity) & & & & & & & & & $\begin{array}{r}-0.00571 \\
(0.0124)\end{array}$ & & \\
\hline External Debt Assets/GDP & & & & & & & & & & $\begin{array}{c}-1.308^{* * *} \\
(0.489)\end{array}$ & \\
\hline External Debt Liabilities/GDP & & & & & & & & & & $\begin{array}{l}1.243^{* *} \\
(0.500)\end{array}$ & \\
\hline Outier FDI dummy & & & & & & & & & & & $\begin{array}{l}0.919^{* *} \\
(0.370)\end{array}$ \\
\hline Observations & 1,489 & 1,780 & 1,729 & 1,832 & 1,826 & 1,784 & 1,764 & 1,739 & 1,819 & 1,832 & 1,832 \\
\hline Pseudo R-squared & 0.32 & 0.30 & 0.31 & 0.31 & 0.31 & 0.31 & 0.31 & 0.31 & 0.31 & 0.31 & 0.31 \\
\hline
\end{tabular}


of GDP growth becomes a significant determinant of crisis risk at a $10 \%$ level. Similar considerations apply to inflation, (HP) trend output growth, trade and financial openness, and institutional quality (polity index): they are statistically insignificant at the 10 percent level (at least) but when entered alone (or when the baseline specification is pruned from other controls), they become significant and correctly signed.

We also break down net positions into their gross counterparts. In the case of debt flows, this breakdown is clearly well motivated theoretically for the reasons discussed in Shin (2012) who suggest that for advanced countries at least, gross debt exposures may matter as much or more than net flows. More broadly but also in a similar vein, Reinhart and Rogoff (2011) focus on gross rather than net external debt in their evidence on the connection between higher debt on lower output growth (which, as shown in Figures 3 and 4, typically follows external crisis outbreaks).

Yet, the results in column (11) suggest that in a broad cross-section of countries over our sample period, net debt is what matters for crisis risk: the coefficients on gross debt assets and gross liabilities are virtually the same and with the opposite sign. Importantly, all the statistically significant coefficients in the baseline specification change little in magnitude with the addition of further controls (and despite some fluctuation in the number of observations due to data availability for some variables). One exception is the coefficient on FDI. This is shown in column (12) of Table 5 which adds a dummy for countries with FDI liabilities in excess of 2 standard deviations from the mean (i.e., FDI liabilities in excess of 55 percent of GDP). By and large, this dummy captures observations associated with small countries with financial centers such as Panama, Jordan, and Malta which have extremely high net FDI liabilities relative to sample mean. While the FDI coefficient does not change sign, the coefficient drops by more than one-half and is no longer statistically significant at conventional levels. ${ }^{11}$

To sum up, barring some instability of the coefficients on net equity positions - and in particular the sensitivity of the FDI coefficient to the inclusion of a few observation for financial centers in the sample - the results above indicate that our estimates are robust to a variety of controls, including to the breakdown between gross and net external positions.

\footnotetext{
${ }^{11}$ As part of our robustness tests, we have also experimented with adding extra fixed effects for every country. None of them changes the economic and statistical significance of the remaining coefficients in our baseline specification. We have also introduced a country-specific credit history defined as in Reinhart et al. (2004). In contrast with what Aizenman and Noy (2012) find for banking crises, such a credit history variable is highly insignificant in our regressions once other controls in place. One reason is that banking crises are sometimes uncorrelated with external crises. Another reason is that the positive effect of crises on savings, documented by Aizenman and Noy, is already controlled for by the inclusion of the current account in our regressions. Finally, we have also considered three other controls -- the world output gap, the weighted average of real short-terms interest rates of G-7 countries, historical growth volatility (measured as 10-year moving averages of real GDP growth). Again, none of them proved to improve on our baseline specification.
} 


\section{E. Robustness to Crisis Definition and Sample Breakdown}

As discussed earlier, our paper focuses on large external crises, rather than on financial crises in general or on sovereign defaults in particular. One might then ask: how would the strength of the above results change with alternative crisis definitions? Table 6 sheds light on this question. Alongside with our baseline crisis definition and preferred specification in column (1), we report probit estimates for three alternative crisis definitions. The first broadens the scope of "external crisis". Specifically, we augment the previous criterion to include any real exchange rate depreciation in excess to 15 percent in any single year or 20 percent in two consecutive years, coupled with negative real GDP growth and/or a drop in the output gap by more than one-standard deviation for each country. ${ }^{12}$ In this broader definition, the number of crises rises from 61 to 80 (see Appendix 1). A comparison of columns (1) and (2) of Table 6 shows that the thrust of the earlier results stands. The fit is only marginally worse (as judged by the pseudo $\mathrm{R}^{2}$ ) but the estimated coefficients retain their significance and sign, except for net portfolio equity which becomes negatively signed though remaining statistically insignificant. ${ }^{13}$

The other alternative definition, reported in column (3) of Table 6, is narrower: it only encompasses sovereign defaults and reschedulings. This is the definition more widely found in the sovereign debt literature (Borenzstein and Pannizza, 2008; Reinhart and Rogoff, 2009). Its downside is to exclude well-known external crises like Argentina and Mexico in 1995, Thailand and Korea in 1997/98, which would likely have turned into defaults in the absence of multilateral assistance. Be that as it may, many of our earlier results remain unchanged. The only significant differences are the coefficient on the current account and FDI (now smaller and less precisely estimated). On the other hand, the coefficient on debt is nearly twice as high and so is that on reserves. This is unsurprising since we are focusing more squarely on debt defaults and entirely in emerging markets, wherein reserve drainage often plays a much greater role (as in first generation crisis models à la Krugman). Also, net FDI liabilities play much less of a role in crisis prevention. Other probit coefficients are broadly consistent and the higher pseudo $\mathrm{R}^{2}$ suggests that our specification if anything fits the data better.

The narrower crisis definition of column (3) sets the stage for a more direct comparison between our results and those of Gourinchas and Obtsfeld (2012). The differences between their default/rescheduling sample and ours are fourfold. First, they exclude advanced economies. Second, they include some emerging markets not included in our sample, some

\footnotetext{
${ }^{12}$ Country by country estimates of the output gap were computed as in Figure 7, i.e. , as deviations of an HP trend with the smoothing factor lambda set to 100 .

${ }^{13}$ Two other differences are the higher coefficient on the current account and the lower coefficient on relative income per capita. Both are reasonably intuitive: the higher coefficient on the current account is due to the inclusion in the broader sample definition of more episodes of current account reversals (which only sometimes are associated with defaults and reschedulings), so the current account plays a greater role. The lower coefficient on per capita income in the broad crisis definition is due to the inclusion of more advanced countries in the sample where such episodes took place (e.g. the European Monetary System crises of the early 1990s).
} 
of which are repeat defaulters according to their definition (such as Cote d'Ivoire and Nigeria). Third, they include as new defaults credit events that in our sample are part of an earlier broader default episode--particularly in Latin America during the 1980s. Finally, they classify as defaults some credit events not labeled as such in other standard sources (such as South Africa in 1993 and Venezuela in 2005). As a result, one ends up with more crisis events for emerging markets and a total number of default observations comparable to ours. Column (4) reports probit results of this definition of crisis on our set of controls. Net debt, reserves and VIX retain significance, but the coefficient on the current account flips sign, and so does per capita GDP, albeit none is statistically significant at conventional levels. The positive coefficient on the current account is explained by the inclusion of several additional default episodes in oil exporters (two in Venezuela and two in Nigeria) occurring with current account surpluses, as well as by the inclusion of "repeat defaults" which occur when a country may be running a current account surplus due to being cut out from international capital markets. The change in coefficient on GDP per capita instead reflects the exclusion of advanced economies - where GDP per capita is much higher and the incidence of crises much lower.

Final sensitivity tests are reported in the last two columns of Table 6, with the baseline specification estimated over the pre-2007 period. Column (5) shows that eliminating the 2008-11 sovereign crises from the sample does not alter the thrust of the results: net foreign net debt continues to be a strong predictor of external crises, with a coefficient of broadly similar magnitude; likewise, pre-crisis current account balance, real exchange rate deviations from a 5-year moving average, global financial conditions (VIX), and GDP per capita continue to be highly significant. One main change relative to the baseline specification of column (1) is that the coefficient on net portfolio equity now becomes negative (i.e., higher portfolio equity liabilities increases crisis risk), albeit still statistically insignificant. The other main change is that statistical significance of FDI asset position is due to outlier emerging markets: moving from column (5) to (6) of Table 6, the size of the FDI/GDP coefficient only drops and its statistical significance also vanishes. This is consistent with what already shown in column (12) of Table 5, the main difference being that, when sample is truncated at 2006, the FDI coefficient generally rises. One reason is that several post-2007 crises occurred in countries with large negative FDI positions (such as those in Central and Eastern Europe). 
Table 6. Robustness to Sample Definition and Estimation Period

\begin{tabular}{|c|c|c|c|c|c|c|}
\hline & $\begin{array}{c}(1) \\
\text { baseline } \\
\text { crisis } \\
\text { definition }\end{array}$ & $\begin{array}{c}(2) \\
\text { broader } \\
\text { crisis } \\
\text { definition }\end{array}$ & $\begin{array}{c}(3) \\
\text { defaults/ } \\
\text { reschedulings } \\
\text { only }\end{array}$ & $\begin{array}{c}\text { (4) } \\
\text { POG-MO } \\
\text { default crisis } \\
\text { definition }\end{array}$ & $\begin{array}{c}(5) \\
\text { baseline } \\
\text { crisis } \\
\text { definition }\end{array}$ & $\begin{array}{c}(6) \\
\text { baseline exc. } \\
\text { FDI liability } \\
\text { outliers }\end{array}$ \\
\hline VARIABLES & $1970-2011$ & $1970-2011$ & $1970-2011$ & $1970-2011$ & 1970-2006 & 1970-2006 \\
\hline Net external debt assets/GDP & $-1.223^{\star *}$ & $-0.991^{* *}$ & $-2.103^{\star \star *}$ & $-1.269^{\star *}$ & $-1.847^{* * *}$ & $-1.678^{* * *}$ \\
\hline \multirow[t]{2}{*}{ Net external portfolio equity/GDP } & 0.534 & -0.741 & 1.090 & 1.659 & -0.433 & -0.543 \\
\hline & $(1.213)$ & $(0.584)$ & (1.737) & $(1.803)$ & (1.181) & $(1.258)$ \\
\hline \multirow[t]{2}{*}{ Net Foreign Direct Investment/GDP } & $1.193^{* * *}$ & $1.429^{* * *}$ & 0.0648 & 0.395 & $1.744^{* * *}$ & 1.154 \\
\hline & $(0.412)$ & $(0.398)$ & $(0.490)$ & $(0.373)$ & $(0.510)$ & $(0.803)$ \\
\hline \multirow[t]{2}{*}{ FX reserves/GDP } & $-3.984^{* * *}$ & $-2.083^{*}$ & $-4.586^{* *}$ & $-9.937^{* * *}$ & $-6.113^{* *}$ & $-7.471^{* * *}$ \\
\hline & $(1.424)$ & (1.104) & $(1.970)$ & (2.046) & (2.399) & (2.193) \\
\hline \multirow{2}{*}{ CA balance/GDP (2 year MA) } & $-2.294^{* * *}$ & $-7.518^{* * *}$ & $-5.612^{*}$ & 4.050 & $-11.04^{* * *}$ & $-12.09^{* * *}$ \\
\hline & $(0.359)$ & $(2.166)$ & $(2.940)$ & $(2.771)$ & $(3.342)$ & $(3.324)$ \\
\hline \multirow[t]{2}{*}{ Relative Per Capita Income } & $-10.40^{* * *}$ & $-1.764^{* * *}$ & $-2.641^{* * *}$ & 0.493 & $-2.116^{* * *}$ & $-2.057^{* * *}$ \\
\hline & (2.439) & $(0.305)$ & $(0.536)$ & $(0.454)$ & $(0.360)$ & $(0.373)$ \\
\hline \multirow[t]{2}{*}{ REER gap } & $2.001^{* * *}$ & $1.898^{* * *}$ & $2.353^{* * *}$ & 0.908 & $2.303^{* * *}$ & $2.160^{* * *}$ \\
\hline & $(0.468)$ & $(0.524)$ & $(0.698)$ & $(0.882)$ & $(0.438)$ & $(0.442)$ \\
\hline \multirow[t]{2}{*}{ VIX } & $0.697^{* * *}$ & $0.653^{* * *}$ & $0.517^{*}$ & $0.497^{*}$ & $1.218^{* * *}$ & $1.092^{* * *}$ \\
\hline & $(0.250)$ & $(0.222)$ & $(0.265)$ & $(0.267)$ & $(0.357)$ & $(0.351)$ \\
\hline \multirow[t]{2}{*}{ Fiscal Gap } & $-5.069 * *$ & $-8.550^{* * *}$ & $-8.211^{* * *}$ & $-7.241^{* * *}$ & $-6.430^{* *}$ & $-5.999^{\star}$ \\
\hline & $(2.505)$ & $(2.808)$ & $(2.732)$ & $(2.147)$ & (3.040) & (3.142) \\
\hline Observations & 1,832 & 1,778 & 1,797 & 1,062 & 1,510 & 1,442 \\
\hline Pseudo R-squared & 0.31 & 0.26 & 0.35 & 0.22 & 0.34 & 0.36 \\
\hline
\end{tabular}

Robust standard errors in parentheses

${ }^{* * *} p<0.01,{ }^{* *} p<0.05,{ }^{*} p<0.1$

To sum up, while distinct definitions of crises and sample breakdowns can have non-trivial effects on point estimates for some of the explanatory variables, including portfolio equity and FDI, the estimated coefficients for net debt, FX reserves, fiscal deficits and global financial conditions (as proxied by the VIX) remain sizeable and statistically significant throughout. No less importantly, regardless of the classification of default or the inclusion or not of large multilateral assistance, AUROC estimates indicate outstanding predictive performance for any of these alternative crisis definitions, once our set of explanatory variables is maintained (Table 7)

\section{Table 7. AUROC for Baseline Probit Using Different Crisis Definitions and Sample Periods}

1) Baseline External Crisis Definition, 1970-2011 0.90

2) Broader External Crisis Definition, 1970-2011 0.90

3) Our Default/Re-schedulings Definition, 1970-2011 0.89

4) POG-MO default definition, 1970-2011 0.85

5) Baseline External Crisis Definition, 1970-2006 0.91 


\section{E. Predictive Power}

Table 8 provides the respective goodness of fit statistics of the final specification for our baseline crisis definition (first column of Table 6). We follow the usual practice in the literature of classifying as correct predictions or "good alarms" if the model predicts a crisis probability above a chosen cut-off point and a crisis actually occurs within a 2 year window. Mutatis mutandis for a definition of false alarm. As noted above, the 'optimal' chosen cut-off will depend on the objectives of the analyst/policy maker given the relative cost of missing a crisis vs. giving a false alarm. It is natural to set such cut-off point above the unconditional crisis probability ( 3 percent in our sample). Table 8 reports on two alternatives: $11 \%$ and $20 \%$. The former ( $10.5 \%$ more precisely) is the cut-off that the ROC curve indicates to be the one that maximizes the signal to noise ratio.

At the more conservative $20 \%$ cut-off, the model correctly predicts 33 out of the 61 crises. This may seem mediocre predictive performance but the flip side is that false alarms are rather infrequent: the model correctly classifies $99 \%$ of all non-crisis observations and $97 \%$ of all observations. For the $11 \%$ cut-off, the model now correctly predicts 42 out of 61 observations; so it correctly calls out more than two thirds of all crises. The cost is of course a larger share of false alarms. Yet, these are only 5\% of all tranquil period observations; overall, the model gets it right $94 \%$ of the time.

Table 8. Baseline Probit Model: In-Sample Predictive Performance

\begin{tabular}{|c|c|c|c|c|c|}
\hline \multirow[b]{3}{*}{ Predicted Tranquility } & \multicolumn{3}{|c|}{ At $20 \%$ cut-off } & \multirow{5}{*}{$\begin{array}{l}\text { Share of good calls = } \\
\text { Share of false alarms= } \\
\text { Correctly Classified = }\end{array}$} & \multirow{5}{*}{$\begin{array}{r}54 \% \\
1 \% \\
97 \%\end{array}$} \\
\hline & No Crisis & Crisis & Total & & \\
\hline & 1747 & 28 & 1775 & & \\
\hline Predicted Crisis & 24 & 33 & 57 & & \\
\hline Total Obs. & 1771 & 61 & 1832 & & \\
\hline \multicolumn{6}{|c|}{ At Max Signal-to-Noise $=10.5 \%$ cut-off } \\
\hline \multirow{4}{*}{$\begin{array}{l}\text { Predicted Tranquility } \\
\text { Predicted Crisis } \\
\text { Total Obs. }\end{array}$} & No Crisis & Crisis & Total & & \\
\hline & 1683 & 19 & 1702 & Share of good calls $=$ & $69 \%$ \\
\hline & 88 & 42 & 130 & Share of false alarms $=$ & $5 \%$ \\
\hline & 1771 & 61 & 1832 & Correctly Classified = & 94 \\
\hline
\end{tabular}

This is better in-sample predictive power than those obtained in earlier studies on EWSs using various probit specifications. For instance, Frankel and Rose's (1996) classic paper uses a much more heavily parameterized model that correctly predicts (at their chosen 25 percent threshold), only 43 percent of crises and correctly classifies 86 percent of observations. Modifications of the Frankel and Rose specification by Berg and Pattillo (1999) increase the share of correct calls at the cost of a high share of false alarms, and overall correct classifications remain around 86 percent. Further, predictive performance is reasonably well-balanced across regions and emerging markets vs advanced economies, with much of the shortfall in in-sample predictive performance being associated with a few episodes in the Africa/Middle East region. 


\section{Table 9. Share of Good Signals to Total Crises by Regions}

\begin{tabular}{|ccccc|}
\hline $\begin{array}{c}\text { Advanced } \\
\text { Countries }\end{array}$ & $\begin{array}{c}\text { Africa \& } \\
\text { Middle East }\end{array}$ & $\begin{array}{c}\text { Emerging } \\
\text { Asia }\end{array}$ & $\begin{array}{c}\text { Emerging } \\
\text { Europe }\end{array}$ & Latin America \\
\hline $67 \%$ & $40 \%$ & $77 \%$ & $60 \%$ & $70 \%$ \\
\hline
\end{tabular}

Last but not least, we look at the out-of-sample predictive performance over 2007-2011. ${ }^{14}$ Using the model estimates over 1970-2006 for the baseline crisis definition (shown in column 5 of Table 6), Table 10 reports the estimated crisis probabilities for the more conservative $20 \%$ cut-off. In the same table we also include countries and years where and when a crisis actually took place but for which the model fell short of predicting a crisis on the basis of the $20 \%$ threshold.

Table 10. Out-of-Sample Predictive Power over 2008-2011 Crises

\begin{tabular}{|c|c|c|c|c|c|c|c|c|c|c|c|c|}
\hline Country & year & crisis & Predicted & $\begin{array}{c}\text { Output } \\
\text { Gap t }\end{array}$ & $\begin{array}{l}\text { Output } \\
\text { Gap t+1 }\end{array}$ & $\begin{array}{c}\text { Lagged } \\
\text { Debt/Y }\end{array}$ & $\begin{array}{c}\text { Previous } \\
\text { year's } \\
\text { Equity/Y }\end{array}$ & $\begin{array}{c}\text { Previous } \\
\text { year's } \\
\text { FDI/Y }\end{array}$ & $\begin{array}{c}\text { Previous } \\
2 \text { years' } \\
\text { CAY }\end{array}$ & $\begin{array}{c}\text { Previous } \\
\text { year's } \\
\text { Fxres/Y }\end{array}$ & $\begin{array}{l}\text { Previous } \\
\text { year's } \\
\text { REERgap }\end{array}$ & $\begin{array}{c}\text { Previous } \\
\text { year's } \\
\text { GGB/Y }\end{array}$ \\
\hline Dominican Rep. & 2009 & 1 & $22 \%$ & $0 \%$ & $2 \%$ & $-10 \%$ & $0 \%$ & $-37 \%$ & $-8 \%$ & $6 \%$ & $11 \%$ & $-3 \%$ \\
\hline Ecuador & 2008 & 1 & $0 \%$ & $3 \%$ & $-1 \%$ & $-4 \%$ & $0 \%$ & $-22 \%$ & $4 \%$ & $7 \%$ & $-12 \%$ & $2 \%$ \\
\hline Greece & 2008 & 0 & $47 \%$ & $8 \%$ & $5 \%$ & $-72 \%$ & $-23 \%$ & $-7 \%$ & $-13 \%$ & $0 \%$ & $4 \%$ & $-7 \%$ \\
\hline Greece & 2009 & 0 & $87 \%$ & $5 \%$ & $3 \%$ & $-70 \%$ & $-2 \%$ & $0 \%$ & $-15 \%$ & $0 \%$ & $5 \%$ & $-10 \%$ \\
\hline Greece & 2010 & 1 & $92 \%$ & $3 \%$ & $-2 \%$ & $-88 \%$ & $-1 \%$ & $-1 \%$ & $-13 \%$ & $0 \%$ & $5 \%$ & $-16 \%$ \\
\hline Hungary & 2008 & 1 & $0 \%$ & $4 \%$ & $-3 \%$ & $-46 \%$ & $-6 \%$ & $-46 \%$ & $-7 \%$ & $22 \%$ & $11 \%$ & $-5 \%$ \\
\hline Jamaica & 2009 & 0 & $51 \%$ & $-1 \%$ & $-3 \%$ & $-44 \%$ & $-1 \%$ & $-69 \%$ & $-18 \%$ & $17 \%$ & $9 \%$ & $-8 \%$ \\
\hline Jamaica & 2010 & 1 & $24 \%$ & $-3 \%$ & $-2 \%$ & $-46 \%$ & $-3 \%$ & $-69 \%$ & $-15 \%$ & $19 \%$ & $-1 \%$ & $-11 \%$ \\
\hline Latvia & 2008 & 1 & $21 \%$ & $14 \%$ & $-8 \%$ & $-46 \%$ & $0 \%$ & $-35 \%$ & $-23 \%$ & $15 \%$ & $8 \%$ & $1 \%$ \\
\hline Lithuania & 2009 & 0 & $32 \%$ & $-8 \%$ & $-6 \%$ & $-28 \%$ & $1 \%$ & $-23 \%$ & $-14 \%$ & $17 \%$ & $9 \%$ & $-3 \%$ \\
\hline Pakistan & 2008 & 1 & $7 \%$ & $2 \%$ & $1 \%$ & $-16 \%$ & $-5 \%$ & $-17 \%$ & $-6 \%$ & $4 \%$ & $2 \%$ & $-5 \%$ \\
\hline Portugal & 2008 & 0 & $29 \%$ & $0 \%$ & $-3 \%$ & $-69 \%$ & $-11 \%$ & $-21 \%$ & $-10 \%$ & $1 \%$ & $3 \%$ & $-3 \%$ \\
\hline Portugal & 2009 & 0 & $69 \%$ & $-3 \%$ & $-1 \%$ & $-70 \%$ & $-10 \%$ & $-15 \%$ & $-11 \%$ & $1 \%$ & $2 \%$ & $-4 \%$ \\
\hline Portugal & 2010 & 0 & $84 \%$ & $-1 \%$ & $-3 \%$ & $-87 \%$ & $-14 \%$ & $-20 \%$ & $-12 \%$ & $2 \%$ & $1 \%$ & $-10 \%$ \\
\hline Portugal & 2011 & 1 & $56 \%$ & $-3 \%$ & $0 \%$ & $-85 \%$ & $-12 \%$ & $-20 \%$ & $-10 \%$ & $1 \%$ & $-1 \%$ & $-10 \%$ \\
\hline Romania & 2009 & 1 & $18 \%$ & $0 \%$ & $-4 \%$ & $-15 \%$ & $-1 \%$ & $-33 \%$ & $-13 \%$ & $25 \%$ & $13 \%$ & $-5 \%$ \\
\hline Serbia & 2009 & 1 & $41 \%$ & $2 \%$ & $0 \%$ & $-26 \%$ & $-1 \%$ & $-32 \%$ & $-20 \%$ & $37 \%$ & $12 \%$ & $-2 \%$ \\
\hline Spain & 2008 & 0 & $25 \%$ & $2 \%$ & $-3 \%$ & $-69 \%$ & $-15 \%$ & $0 \%$ & $-9 \%$ & $1 \%$ & $5 \%$ & $2 \%$ \\
\hline Spain & 2009 & 0 & $72 \%$ & $-3 \%$ & $-3 \%$ & $-66 \%$ & $-9 \%$ & $0 \%$ & $-10 \%$ & $1 \%$ & $6 \%$ & $-4 \%$ \\
\hline Spain & 2010 & 0 & $80 \%$ & $-3 \%$ & $-3 \%$ & $-83 \%$ & $-14 \%$ & $0 \%$ & $-7 \%$ & $1 \%$ & $4 \%$ & $-11 \%$ \\
\hline Spain & 2011 & 0 & $43 \%$ & $-3 \%$ & $0 \%$ & $-85 \%$ & $-9 \%$ & $2 \%$ & $-5 \%$ & $2 \%$ & $0 \%$ & $-9 \%$ \\
\hline Turkey & 2008 & 1 & $2 \%$ & $1 \%$ & $-4 \%$ & $-17 \%$ & $-10 \%$ & $-22 \%$ & $-6 \%$ & $10 \%$ & $19 \%$ & $-2 \%$ \\
\hline Ukraine & 2008 & 1 & $0 \%$ & $4 \%$ & $-7 \%$ & $5 \%$ & $-1 \%$ & $-22 \%$ & $-3 \%$ & $17 \%$ & $7 \%$ & $-2 \%$ \\
\hline
\end{tabular}

${ }^{14}$ Of course what we call out-of-sample performance is not genuinely out of sample in the sense that the events that we seek to predict have already taken place and, hence, our choice of variables could have been informed by this knowledge. Yet, our choice of variables is standard from the viewpoint of theory and the previous empirical literature on debt crises, and does not include variables proxying bank exposures or other financial vulnerability variables found in post-2007 studies seeking to explain 2008-09 events. 
The model correctly predicts the Greece and Portugal debt crises events, and also singles out Spain as a high-risk case, with signals "flashing red" since 2008, and relying solely on information on pre-crisis fundamentals. It also correctly predicts the crises in the Dominican Republic, Jamaica, Latvia, Romania (at an 18 percent threshold), and Serbia. While it gives a "false" alarm for Lithuania as per our strict crisis definition, the model correctly picks up the major recession that ensued, as indicated by large negative output gaps in the crisis outbreak year as well as the year after that ( -8 percent and -6 percent respectively).

The model clearly misses the crisis events in Ecuador, Hungary, and the Ukraine (for Pakistan, the estimated 7 percent probability is below the threshold but more than twice the sample's unconditional crisis probability of 3 percent). A special case is Turkey-because of the disbursement of the pre-approved final tranche of IMF lending in 2008 brought its IMF exposure over 200 percent of quota, our coding classifies it as a crisis event, even though Turkey country risk was clearly dropping and the country did not experience a "proper" external crisis. Overall, we conclude that our parsimonious model does a good job at predicting out-of-sample the bulk of the 2008-2011 crises.

\section{CONCLUding REMARKS}

Conventional wisdom associates large external debt liabilities with the likelihood of external crises. This paper corroborates and sharpens this wisdom on four fronts. First, a simple decomposition of the net foreign asset position of a country into its net debt and net equity components shows that net debt liabilities are the most important determinant among all components of NFA and that their contribution to crisis risk is highly statistically significant and reasonably stable across specifications. Second, we provide new evidence on threshold effects. We find that net foreign liabilities in excess of 50 percent of GDP in absolute terms and higher than 20 percent of the country specific historical mean are associated with steeper crisis risk. All else constant, we also find that such a tipping point is typically associated with net external debt liabilities above 35 percent of GDP. Third, the speed at which overall foreign liabilities accumulate, as measured the size of current account deficits, is also key. We find that this speed effect is strong for both conditional and unconditional measures of the current account "gap", but also find that the unconditional measure of current account balance performs better than standard regression-based estimates of current account misalignment. Fourth, we find some support for the role of reserve accumulation in crisis prevention, and no evidence that higher net FDI liabilities - controlling for other factors such as the current account balance-increase crisis risk.

Finally, we show that a parsimonious probit specification including these NFA components as well as the current account balance and a handful of other variables does a very respectable job in explaining external crises. In particular, when estimated over the period 1970-2006, such a model correctly predicts out-of-sample most of the 2008-11 crises. This suggests that while the triggers of the global financial crisis may have been different from previous crisis episodes, the countries experiencing an external crisis had macroeconomic and external balance sheet characteristics similar to those associated with past crisis episodes. 


\section{REFERENCES}

Abiad, Abdul, 2003, "Early Warning Systems: A Survey and a Regime-Switching Approach, IMF Working Paper 03/32.

Aguiar, Mark and Gopinath, Gita, 2006, " Defaultable debt, interest rates and the current account”, Journal of International Economics, 69(1), 61-89.

Alfaro, Laura, Sebnem Kalemli-Ozcan, and Vadym Volosovych, 2012, "Sovereigns, Upstream Capital Flows, and Global Imbalances”, unpublished manuscript.

Arellano, Cristina, 2008, "Default risk and income fluctuations in emerging economies," American Economic Review, 98(3), pp. 690-712

Aizenman, Joshua and Ilan Noy, 2012, "Macroeconomic Adjustment and the History of Crises in Open Economies”, NBER working paper 18527.

Beim, David O., and Charles W. Calomiris, 2001, Emerging Financial Markets (New York: McGraw-Hill/Irwin).

Berg, Andrew and Catherine Pattillo, 1999, "Are Currency Crises Predictable? A Test", IMF Staff Papers, 46, No. 2.

Borensztein, Eduardo, Jose de Gregorio, and J-W Lee, 1998, "How Does Foreign Direct Investment Affect Economic Growth?," Journal of International Economics, 45, pp.115-135.

Borensztein, Eduardo and Panizza, Ugo, 2008, "The Costs of Sovereign Defaults", IMF working paper 238.

Bussière. Matthieu and Marcel Fratzscher, 2006, “Towards a New Early Warning System of Financial Crises”, Journal of International Money and Finance, 25(6), pp. 953-973.

Calvo, Guillermo, 1998, "Capital Flows and Capital Market Crises: The Simple Economics of Sudden Stops," Journal of Applied Economics, 1.

Calvo, Guillermo, Alejandro Izquierdo, and Luis Mejia, 2004, "On the Empirics of Sudden Stops," NBER Working Paper.

Catão, Luis, Ana Fostel, and Sandeep Kapur, S. 2009, "Persistent Gaps and Default Traps", Journal of Development Economics, 89, pp.271-84.

Chinn, Menzie and Eswar Prasad, 2003, "Medium-term Determinants of Current Accounts in Industrial and Developing Countries", Journal of International Economics, 59(1), pp. 47-76

Chinn, Menzie, Barry Eichengreen, and Hiro Ito, 2011, “A Forensic Analysis of Global Imbalances", Unpublished manuscript. 
Edwards, Sebastian, 2004, "Thirty Years of Current Account Imbalances, Current Account Reversals, and Sudden Stops", IMF Staff Papers, 51, pp. 1-49.

Eichengreen, Barry, Andrew K. Rose, and Charles Wyplosz, 1996, “Contagious Currency Crises,” NBER Working Paper No. 5681 (Cambridge, Massachusetts: National Bureau of Economic Research).

Faria, Andre, Philip Lane, Paolo Mauro, and Gian Maria Milesi-Ferretti, 2007, "The Shifting Composition of External Liabilities", Journal of European Economic Association, 5, pp.480-90.

Flood, Robert, and Nancy Marion, 1998, "Perspectives on the Recent Currency Crisis Literature," NBER Working Paper No. 6380 (Cambridge, Massachusetts: National Bureau of Economic Research)

Frankel, Jeffrey A., and Andrew K. Rose, 1996, "Currency Crashes in Emerging Markets: An Empirical Treatment," Journal of International Economics, 41, pp. 351-66.

Frankel, Jeffrey A. and George Saravelos, 2012, "Can Leading Indicators Assess Country Vulnerability? Evidence from the 2008-09 Global Financial Crisis," Journal of International Economics, 87 (2), pp. 216-231.

Gourinchas, Pierre-Olivier, and Maurice Obstfeld, 2012. "Stories of the Twentieth Century for the Twenty-First." American Economic Journal: Macroeconomics, 4(1): 226-65.

Hausmann, Ricardo and Eduardo Fernandez-Arias, 2001, "Is Foreign Direct Investment a Safer Form of Financing?," Emerging Markets Review, vol. 2, 1, pp. 34-48.

Jordá, O, Alan M. Taylor and Moritz Schularick, 2011, "Financial Crises, Credit Booms, and External Imbalances: 140 Years of Lessons”, IMF Economic Review, 59, pp.340-378

Kaminsky, Graciela, Saul Lizondo, and Carmen Reinhart, 1998, "Leading Indicators of Currency Crises,” Staff Papers, International Monetary Fund, Vol. 45, pp. 1-48.

Kaminsky, Graciela and Carmen M. Reinhart, 1999, "The Twin Crises: The Causes of Banking and Balance-of-Payments Problems," American Economic Review, 89(3), pp. 473-500

Kraay, Aart, and Vikram Nehru, 2006, “When is External Debt Sustainable?” World Bank Economic Review, 20, pp.341-365

Lane, Philip R. and Gian Maria Milesi-Ferretti, 2007, "The External Wealth of Nations Mark II: Revised and Extended Estimates of External Assets and Liabilities," Journal of International Economics, vol.73, pp. 223-50.

Lane, Philip R. and Gian Maria Milesi-Ferretti, 2012, "External Adjustment and the Global Crisis," Journal of International Economics, 88, pp. 252-265. 
Lee, Jaewoo, Gian Maria Milesi-Ferretti, Jonathan Ostry, Alessandro Prati, and Luca Ricci, 2008, Exchange Rate Assessments: CGER Methodologies, IMF occasional paper 261.

Levy-Yeyati, Eduardo and Ugo Panizza, 2011, "The Elusive Costs of Sovereign Default", Journal of Development Economics, 94(1), pp. 95-105.

Mendoza, Enrique and Vivian Yue, 2012, “A General Equilibrium Model of Sovereign Default and Business Cycles", Quarterly Journal of Economics, 127, pp.889-946.

Milesi-Ferretti, Gian Maria and Assaf Razin, 2000, "Current Account Reversals and Currency Crises: Empirical Regularities”, in Krugman, P (ed.), Currency crises, Chicago: University of Chicago Press for NBER.

Obstfeld, Maurice, and Kenneth Rogoff, 1996, Foundations of International Macroeconomics, (Cambridge, Massachusetts: MIT Press).

Obstfeld, Maurice, Jay Shambaugh, and Alan Taylor, 2010, "Financial Stability, the Trilemma, and International Reserves," American Economic Journal: Macroeconomics, 2, pp. 57-94.

Panizza, Ugo, Jeromin Zettelmeyer and Federico Sturzenegger, 2009, "The Economics and Law of Sovereign Debt and Default", Journal of Economic Literature, 47(3), pp. 651-698.

Pistelli, Alfredo, Jorge Selaive, and Rodrigo Valdes, 2008, "Stock, Flows, and Valuation Effects of Foreign Assets and Liabilities: Do They Matter?", in Cowan, K et al. (eds), Current Account and External Finance, Central Bank of Chile.

Reinhart, Carmen and Kenneth Rogoff, 2009, This Time is Different. Eight Centuries of Financial Folly, Princeton University Press.

Reinhart, Carmen and Kenneth Rogoff, 2010, "Growth in a Time of Debt", American Economic Review, Papers and Proceedings 100, pp. 573-578.

Reinhart, Carmen and Kenneth Rogoff, and Miguel Savastano, 2003, "Debt Intolerance”, Brooking papers in Economic Activity, 34(1), pp. 1-74.

Sachs, Jeffrey, and Daniel Cohen, 1985, "LDC Borrowing with Default Risk," Kredit und Kapital, pp. 211-35.

Satchell, Steven and Xia Wei, 2006, "Analytic Models of the ROC curve: Applications to Credit Rating Model Validation,” Working paper 181, UT Sidney.

Shin, Hyun Song, 2012, "Global Banking Glut and Loan Risk Premium," IMF Economic Review, 60, pp.155-192. 
Shularick, Moritz and Alan M. Taylor, 2012, "Credit Booms Gone Bust: Monetary Policy, Leverage Cycles, and Financial Crises, 1870-2008”, American Economic Review, 102(2), pp. 1029-61.

Wright, Mark, 2006, "Private Capital Flows, Capital Controls and Default Risk", Journal of International Economics, 69, pp. 120-149. 


\section{Appendix 1: Sample}

\begin{tabular}{|c|c|c|c|c|c|c|c|c|c|}
\hline \multirow[b]{2}{*}{ Country } & \multicolumn{3}{|c|}{ Overall Sample } & & \multicolumn{3}{|c|}{ Crisis Sample (baseline definition) } & \multicolumn{2}{|c|}{ Crisis Sample (broader crisis definition) } \\
\hline & ifs_code & em & adv & & Country & Year & Default & Country & Year \\
\hline Australia & 193 & 0 & 1 & 1 & Argentina & 1982 & 1 & Argentina & 1975 \\
\hline Austria & 122 & 0 & 1 & 1 & Argentina & 1995 & 0 & Argentina & 1982 \\
\hline Belgium & 124 & 0 & 1 & 1 & Argentina & 2001 & 1 & Argentina & 1995 \\
\hline Belize & 339 & 1 & 0 & 1 & Belize & 2006 & 1 & Belize & 2006 \\
\hline Brazil & 223 & 1 & 0 & 1 & Brazil & 1983 & 1 & Argentina & 2001 \\
\hline Bulgaria & 918 & 1 & 0 & 1 & Brazil & 1999 & 0 & Brazil & 1983 \\
\hline Canada & 156 & 0 & 1 & 1 & Brazil & 2001 & 0 & Brazil & 1999 \\
\hline Chile & 228 & 1 & 0 & 1 & Chile & 1972 & 1 & Brazil & 2001 \\
\hline China & 924 & 1 & 0 & 1 & Chile & 1983 & 1 & Chile & 1972 \\
\hline Colombia & 233 & 1 & 0 & 1 & Costa Rica & 1981 & 1 & Chile & 1983 \\
\hline Costa Rica & 238 & 1 & 0 & 1 & Dominican R & 1982 & 1 & Costa Rica & 1981 \\
\hline Croatia & 960 & 1 & 0 & 1 & Dominican R & 2003 & 1 & Dominican Republic & 1982 \\
\hline Cyprus & 423 & 0 & 1 & 1 & Dominican $\mathrm{R}$ & 2009 & 0 & Dominican Republic & 2003 \\
\hline Czech Republic & 935 & 1 & 0 & 1 & Ecuador & 1983 & 1 & Dominican Republic & 2009 \\
\hline Denmark & 128 & 0 & 1 & 1 & Ecuador & 1999 & 1 & Ecuador & 1983 \\
\hline Dominican Republic & 243 & 1 & 0 & 1 & Ecuador & 2008 & 1 & Ecuador & 1999 \\
\hline Ecuador & 248 & 1 & 0 & 1 & Egypt & 1984 & 1 & Ecuador & 2008 \\
\hline Egypt & 469 & 1 & 0 & 1 & Greece & 2010 & 0 & Egypt & 1984 \\
\hline El Salvador & 253 & 1 & 0 & 1 & Hungary & 2008 & 1 & Finland & 1993 \\
\hline Estonia & 939 & 1 & 0 & 1 & Iceland & 1976 & 0 & Greece & 2010 \\
\hline Finland & 172 & 0 & 1 & 1 & India & 1984 & 0 & Guatemala & 1985 \\
\hline France & 132 & 0 & 1 & 1 & Indonesia & 1998 & 1 & Hungary & 2008 \\
\hline Germany & 134 & 0 & 1 & 1 & Israel & 1976 & 0 & Iceland & 1975 \\
\hline Greece & 174 & 0 & 1 & 1 & Italy & 1975 & 0 & Iceland & 1983 \\
\hline Guatemala & 258 & 1 & 0 & 1 & Jamaica & 1978 & 1 & India & 1984 \\
\hline Hong Kong & 532 & 0 & 1 & 1 & Jamaica & 2010 & 1 & India & 1991 \\
\hline Hungary & 944 & 1 & 0 & 1 & Jordan & 1989 & 1 & Indonesia & 1998 \\
\hline India & 534 & 1 & 0 & 1 & Jordan & 1997 & 0 & Israel & 1976 \\
\hline Indonesia & 536 & 1 & 0 & 1 & Jordan & 2002 & 0 & Italy & 1975 \\
\hline Israel & 436 & 0 & 1 & 1 & Korea & 1975 & 0 & Italy & 1993 \\
\hline Italy & 136 & 0 & 1 & 1 & Korea & 1980 & 0 & Jamaica & 1978 \\
\hline Jamaica & 343 & 1 & 0 & 1 & Korea & 1997 & 0 & Jamaica & 2010 \\
\hline Japan & 158 & 0 & 1 & 1 & Latvia & 2008 & 0 & Jordan & 1989 \\
\hline Jordan & 439 & 1 & 0 & 1 & Mexico & 1982 & 1 & Jordan & 1997 \\
\hline Korea & 542 & 0 & 1 & 1 & Mexico & 1995 & 0 & Jordan & 2002 \\
\hline Latvia & 941 & 1 & 0 & 1 & Morocco & 1981 & 0 & Korea & 1975 \\
\hline Lithuania & 946 & 1 & 0 & 1 & Pakistan & 1981 & 0 & Korea & 1980 \\
\hline Malaysia & 548 & 1 & 0 & 1 & Pakistan & 1998 & 1 & Korea & 1997 \\
\hline Malta & 181 & 0 & 1 & 1 & Pakistan & 2008 & 0 & Korea & 2009 \\
\hline
\end{tabular}




\section{Appendix 1: Sample (cont.)}

\begin{tabular}{|c|c|c|c|c|c|c|c|}
\hline \multirow[b]{2}{*}{ Country } & \multicolumn{3}{|c|}{ Overall Sample } & & \multicolumn{3}{|c|}{ Crisis Sample (baseline definition) } \\
\hline & ifs_code & em & adv & & Country & Year & Default \\
\hline Mexico & 273 & 1 & 0 & 1 & Panama & 1983 & 1 \\
\hline Morocco & 686 & 1 & 0 & 1 & Peru & 1978 & 1 \\
\hline Netherlands & 138 & 0 & 1 & 1 & Peru & 1982 & 0 \\
\hline New Zealand & 196 & 0 & 1 & 1 & Philippines & 1976 & 0 \\
\hline Norway & 142 & 0 & 1 & 1 & Philippines & 1983 & 1 \\
\hline Oman & 449 & 1 & 0 & 1 & Poland & 1981 & 1 \\
\hline Pakistan & 564 & 1 & 0 & 1 & Portugal & 1977 & 0 \\
\hline Panama & 283 & 1 & 0 & 1 & Portugal & 2011 & 0 \\
\hline Peru & 293 & 1 & 0 & 1 & Romania & 2009 & 0 \\
\hline Philippines & 566 & 1 & 0 & 1 & Serbia & 2009 & 1 \\
\hline Poland & 964 & 1 & 0 & 1 & South Africa & 1985 & 1 \\
\hline Portugal & 182 & 0 & 1 & 1 & Thailand & 1981 & 0 \\
\hline Romania & 968 & 1 & 0 & 1 & Thailand & 1985 & 0 \\
\hline Russia & 922 & 1 & 0 & 1 & Thailand & 1997 & 1 \\
\hline Serbia & 942 & 1 & 0 & 1 & Turkey & 1976 & 0 \\
\hline Singapore & 576 & 0 & 1 & 1 & Turkey & 2000 & 0 \\
\hline Slovak Republic & 936 & 1 & 0 & 1 & Turkey & 2008 & 0 \\
\hline Slovenia & 961 & 0 & 1 & 1 & Ukraine & 1998 & 1 \\
\hline South Africa & 199 & 1 & 0 & 1 & Ukraine & 2008 & 0 \\
\hline Spain & 184 & 0 & 1 & 1 & Uruguay & 1983 & 1 \\
\hline Sweden & 144 & 0 & 1 & 1 & Uruguay & 2002 & 0 \\
\hline Switzerland & 146 & 0 & 1 & 1 & Venezuela & 1983 & 1 \\
\hline Taiwan & 528 & 0 & 1 & 1 & & & \\
\hline Thailand & 578 & 1 & 0 & 1 & & & \\
\hline Turkey & 186 & 1 & 0 & 1 & & & \\
\hline Ukraine & 926 & 1 & 0 & 1 & & & \\
\hline United Kingdom & 112 & 0 & 1 & 1 & & & \\
\hline United States & 111 & 0 & 1 & 1 & & & \\
\hline Uruguay & 298 & 1 & 0 & 1 & & & \\
\hline Venezuela & 299 & 1 & 0 & 1 & & & \\
\hline
\end{tabular}

Crisis Sample (broader crisis definition)

\begin{tabular}{|c|c|}
\hline Country & Year \\
\hline Latvia & 2008 \\
\hline Malaysia & 1986 \\
\hline Malaysia & 1998 \\
\hline Mexico & 1982 \\
\hline Mexico & 1995 \\
\hline Morocco & 1981 \\
\hline Oman & 1987 \\
\hline Pakistan & 1972 \\
\hline Pakistan & 1981 \\
\hline Pakistan & 1998 \\
\hline Pakistan & 2008 \\
\hline Panama & 1983 \\
\hline Peru & 1978 \\
\hline Peru & 1982 \\
\hline Philippines & 1976 \\
\hline Philippines & 1983 \\
\hline Philippines & 1998 \\
\hline Poland & 1981 \\
\hline Portugal & 1977 \\
\hline Portugal & 2011 \\
\hline Romania & 1999 \\
\hline Romania & 2009 \\
\hline Serbia & 2009 \\
\hline South Africa & 1985 \\
\hline Sweden & 1993 \\
\hline Thailand & 1981 \\
\hline Thailand & 1985 \\
\hline Thailand & 1997 \\
\hline Turkey & 1976 \\
\hline Turkey & 1994 \\
\hline Turkey & 2000 \\
\hline Turkey & 2008 \\
\hline Ukraine & 1998 \\
\hline Ukraine & 2008 \\
\hline United Kingdom & 2009 \\
\hline Uruguay & 1972 \\
\hline Uruguay & 1983 \\
\hline Uruguay & 2002 \\
\hline Venezuela & 1983 \\
\hline Venezuela & 1996 \\
\hline Venezuela & 2002 \\
\hline
\end{tabular}




\section{Appendix 2. Estimates of Current Account Gaps}

This reports the methodology and econometric estimates of current accounts based on the macroeconomic balance approach to the estimation of current account "norms" implemented in the IMF (see Lee et al, 2007; http://www.imf.org/external/np/res/eba/).

The approach hinges on the inter-temporal Saving-Investment model starting with Obstfeld and Rogoff (1996), empirically implemented and extended in several subsequent contributions (see, e.g., Chinn \& Prasad, 2003; Chinn et al, 2011).

The model can be concisely written by combining the I-S behavioral relation with intratemporal (accounting) and inter-temporal constraints in four equations:

I-S: $\quad \frac{C A}{Y}\left(\right.$ reer,$\left.\tilde{y}^{w o}\right)=\frac{S}{Y}\left(n f a, r, x_{s}\right)-\frac{I}{Y}\left(r\right.$, reer,$\left.x_{I}\right)$

BOP constraint: $\quad \frac{C A}{Y}\left(\right.$ reer, $\left.\tilde{y}^{w o}\right)+\frac{F A}{Y}\left(r-r^{w o}, x_{C F}\right)=\Delta \operatorname{Re} s\left(r-r^{w o}, x_{R S}\right)$

Solvency Constraint: $\quad n f a_{t}=-E_{t} \sum_{j=1}^{\infty} \prod_{k=1}^{\infty} \rho_{t+k}\left[t b_{t+j}+\frac{s_{t+j} a_{t+j}}{\rho_{t+j}\left(1+r_{t+j}^{*}\right)}\right]$

Multilateral Constraint: $\quad \sum_{i=1}^{N} C A_{i}=\sum_{i=1}^{N} \frac{C A_{i}}{Y_{i}} \omega_{i}=0$

where $\omega_{i}$ is the respective share of country $\mathrm{i}$ in world GDP so that globally $\sum_{j=1}^{N} \omega_{j}^{i}=1, \quad \forall \mathrm{i}$.

The model then closes with a policy rule that relates each country's real interest rate $r$ to the output gap $\tilde{y}_{i_{t}}$ and the world interest rate $r^{w o}$. If the country floats its exchange rate and follows (approximately) an IT regime, this relationship can be written as:

$$
\begin{gathered}
c a_{i t}=f\left[n f a_{i_{t}}, \tilde{y}_{i_{t}}-\tilde{y}_{t}^{w o}, \mathbf{x}_{I_{i_{t}}}-\mathbf{x}_{I_{t}}^{w o}, \mathbf{x}_{S_{i_{t}}}-\mathbf{x}_{S_{t}}^{w o}, \mathbf{x}_{C F_{t_{t}}}-\mathbf{x}_{C F_{t}}^{w o}\right] \\
r_{t}=r^{N}+\left(\alpha_{y}+\lambda\right) \tilde{y}_{t}+\varsigma_{t}
\end{gathered}
$$

If instead, the country pegs, this becomes:

$$
\begin{aligned}
& r_{t}=i_{t}^{w o}-E\left(\pi_{t+1}\right)=r_{t}^{w o}-E\left(\pi_{t+1}-\pi_{t+1}^{w o}\right) \\
& =r_{t}^{w o}-f\left(\tilde{y}_{t}, \tilde{y}_{t}^{w o}\right)
\end{aligned}
$$

In reduced-form, the model solves for the current account ratio to GDP: 


$$
c a_{i t}=f\left[n f a_{i_{t}}, \tilde{y}_{i_{t}}-\tilde{y}_{t}^{w o}, \mathbf{x}_{I_{i_{t}}}-\mathbf{x}_{I_{t}}^{w o}, \mathbf{x}_{S_{i_{t}}}-\mathbf{x}_{S_{t}}^{w o}, \mathbf{x}_{C F_{i_{t}}}-\mathbf{x}_{C F_{t}}^{w o}, \mathbf{x}_{R S_{i_{t}}}-\mathbf{x}_{C F_{t}}^{w o}\right]
$$

where $\mathbf{x}$ 's are:

$\mathbf{x}_{s}=$ the consumption/saving shifters, which include income per capita, demographics, expected income (shifts in permanent income), social insurance, and the budget balance;

$\mathbf{x}_{I}=$ the investment shifters, which include income per capita, TFP (or output trend growth as usually measured), governance, and other indicators that can be plausibility assumed to drive domestic capital formation.

$\mathbf{x}_{C F}=$ capital account shifters, which include indicators of global risk aversion, and capital controls.

$\mathbf{x}_{R S}=$ reserve accumulation shifters, which include all precautionary as well as policy factors (including capital controls), driving reserve accumulation.

Note that multilateral constraint (4) implies that each country's variable should be measured relative to a (current GDP) weighted world average of the same variable. This implies that the world interest rate term will drop out. If the emphasizes is long-run equilibrium, the output gap term will $\tilde{y}_{i_{t}}-\tilde{y}_{t}^{\text {wo }}$ will also drop out. So will cyclical influences associated with bouts of global risk aversion and asymmetric reserve accumulation.

The first column of Table A2 reports our baseline estimate of equation (6), using standard proxies for the various savings and investment shifters, and annual panel data for 1970-2011. Columns (2) to (6) reports alternative specifications. They indicate that the chosen baseline is robust to those alternative controls. In the main text, we use the residuals of specification (1) as our measure of the country's current account gap. 
Table A2. Panel Estimates of Current Account Norms

\begin{tabular}{|c|c|c|c|c|c|c|}
\hline & (1) & (2) & (3) & (4) & (5) & (6) \\
\hline VARIABLES & $\mathrm{CA} / \mathrm{Y}$ & $\mathrm{CA} / \mathrm{Y}$ & $\mathrm{CA} / \mathrm{Y}$ & $\mathrm{CA} / \mathrm{Y}$ & $\mathrm{CA} / \mathrm{Y}$ & $\mathrm{CA} / \mathrm{Y}$ \\
\hline Lagged NFA/Y & $\begin{array}{l}0.0452^{* * *} \\
(0.00346)\end{array}$ & $\begin{array}{l}0.0455^{* * *} \\
(0.00351)\end{array}$ & $\begin{array}{l}0.0442^{* * *} \\
(0.00398)\end{array}$ & $\begin{array}{l}0.0465^{\star * *} \\
(0.00353)\end{array}$ & $\begin{array}{l}0.0452^{* * *} \\
(0.00346)\end{array}$ & $\begin{array}{l}0.0473^{* * *} \\
(0.00370)\end{array}$ \\
\hline Relative PPP GDPpc & $\begin{array}{l}0.0467^{\star \star *} \\
(0.00563)\end{array}$ & $\begin{array}{l}0.0480^{\star * *} \\
(0.00592)\end{array}$ & $\begin{array}{l}0.0459^{\star * *} \\
(0.00584)\end{array}$ & $\begin{array}{l}0.0445^{\star \star *} \\
(0.00582)\end{array}$ & $\begin{array}{l}0.0465^{\star \star *} \\
(0.00566)\end{array}$ & $\begin{array}{l}0.0185^{\star * *} \\
(0.00592)\end{array}$ \\
\hline Oil Balance Dummy & $\begin{array}{l}0.287^{* * *} \\
(0.0471)\end{array}$ & $\begin{array}{l}0.285^{* * *} \\
(0.0471)\end{array}$ & $\begin{array}{l}0.291^{* * *} \\
(0.0475)\end{array}$ & $\begin{array}{l}0.277^{* * *} \\
(0.0466)\end{array}$ & $\begin{array}{l}0.287^{* * *} \\
(0.0472)\end{array}$ & $\begin{array}{l}0.356^{* * *} \\
(0.0700)\end{array}$ \\
\hline Old Age Depency Ratio & $\begin{array}{c}-0.143^{\star * *} \\
(0.0246)\end{array}$ & $\begin{array}{c}-0.145^{\star * *} \\
(0.0250)\end{array}$ & $\begin{array}{c}-0.140^{* * *} \\
(0.0250)\end{array}$ & $\begin{array}{c}-0.140^{\star * *} \\
(0.0257)\end{array}$ & $\begin{array}{c}-0.142^{\star * *} \\
(0.0246)\end{array}$ & $\begin{array}{c}-0.0802^{* \star *} \\
(0.0245)\end{array}$ \\
\hline Population Growth & $\begin{array}{c}-0.402^{* *} \\
(0.174)\end{array}$ & $\begin{array}{c}-0.413^{\star *} \\
(0.177)\end{array}$ & $\begin{array}{c}-0.407^{\star *} \\
(0.175)\end{array}$ & $\begin{array}{c}-0.423^{\star *} \\
(0.184)\end{array}$ & $\begin{array}{c}-0.400^{\star *} \\
(0.174)\end{array}$ & $\begin{array}{c}-0.460^{\star \star} \\
(0.191)\end{array}$ \\
\hline Polity Index & $\begin{array}{c}-0.000747^{* * *} \\
(0.000189)\end{array}$ & $\begin{array}{c}-0.000769^{* * *} \\
(0.000194)\end{array}$ & $\begin{array}{c}-0.000726^{\star * *} \\
(0.000186)\end{array}$ & $\begin{array}{c}-0.000781^{* * *} \\
(0.000206)\end{array}$ & $\begin{array}{c}-0.000746^{* * *} \\
(0.000190)\end{array}$ & $\begin{array}{l}-0.000214 \\
(0.000192)\end{array}$ \\
\hline Trend Growth & $\begin{array}{c}-0.262^{\star * *} \\
(0.0574)\end{array}$ & $\begin{array}{c}-0.264^{\star * *} \\
(0.0575)\end{array}$ & $\begin{array}{c}-0.260^{\star * *} \\
(0.0588)\end{array}$ & $\begin{array}{c}-0.265^{\star \star *} \\
(0.0555)\end{array}$ & $\begin{array}{c}-0.262^{* * *} \\
(0.0574)\end{array}$ & $\begin{array}{c}-0.291^{* * *} \\
(0.0675)\end{array}$ \\
\hline General Gov. Balance (cyc.adj) & $\begin{array}{l}0.375^{\star * *} \\
(0.0580)\end{array}$ & $\begin{array}{l}0.375^{\star * *} \\
(0.0583)\end{array}$ & $\begin{array}{l}0.369^{* * *} \\
(0.0556)\end{array}$ & $\begin{array}{l}0.456^{* * *} \\
(0.0578)\end{array}$ & $\begin{array}{l}0.377^{* * *} \\
(0.0585)\end{array}$ & $\begin{array}{l}0.452^{* * *} \\
(0.0616)\end{array}$ \\
\hline Quinn Index of Capital Controls & $\begin{array}{l}0.0226^{* * *} \\
(0.00469)\end{array}$ & $\begin{array}{l}0.0228^{* * *} \\
(0.00473)\end{array}$ & $\begin{array}{l}0.0232^{* * *} \\
(0.00462)\end{array}$ & $\begin{array}{l}0.0224^{* * *} \\
(0.00499)\end{array}$ & $\begin{array}{l}0.0227^{\star * *} \\
(0.00480)\end{array}$ & $\begin{array}{l}0.0160^{\star * *} \\
(0.00575)\end{array}$ \\
\hline Aging Speed & & $\begin{array}{l}-0.0131 \\
(0.0203)\end{array}$ & & & & \\
\hline Financial Center Dummy & & & $\begin{array}{c}0.00395 \\
(0.00654)\end{array}$ & & & \\
\hline Trade Openness (5-year MA) & & & & $\begin{array}{c}-0.00222 \\
(0.00598)\end{array}$ & & \\
\hline Reserve Currency Dummy & & & & & $\begin{array}{l}0.000841 \\
(0.00300)\end{array}$ & \\
\hline Social Protection Index & & & & & & $\begin{array}{c}-0.0132 \\
(0.00938)\end{array}$ \\
\hline Constant & $\begin{array}{l}0.0103^{* * *} \\
(0.00227)\end{array}$ & $\begin{array}{l}0.0106^{* * *} \\
(0.00231)\end{array}$ & $\begin{array}{c}0.00943^{* * *} \\
(0.00270)\end{array}$ & $\begin{array}{l}0.0104^{* * *} \\
(0.00313)\end{array}$ & $\begin{array}{l}0.0102^{* * *} \\
(0.00239)\end{array}$ & $\begin{array}{l}0.00498^{* *} \\
(0.00232)\end{array}$ \\
\hline Observations & 2,300 & 2,300 & 2,300 & 2,134 & 2,300 & 1,891 \\
\hline R-squared & 0.319 & 0.319 & 0.319 & 0.341 & 0.319 & 0.344 \\
\hline
\end{tabular}

Robust SEs in parentheses

${ }^{* * *} p<0.01,{ }^{* *} p<0.05,{ }^{*} p<0.1$ 